\title{
Extracting key factors for sustainable development of enterprises: Case study of SMEs in Taiwan
}

Ville Matinaro, Yang Liu, Tzong-Ru (J iun-Shen) Lee and J urgen Poesche

The self-archived postprint version of this journal article is available at Linköping University Institutional Repository (DiVA):

http:/ / urn.kb.se/ resolve?urn=urn:nbn:se:liu:diva- 154572

N.B.: When citing this work, cite the original publication.

Matinaro, V., Liu, Y., Lee, T. R., Poesche, J ., (2019), Extracting key factors for sustainable development of enterprises: Case study of SMEs in Taiwan, J ournal of Cleaner Production, 209, 1152-1169. https:// doi.org/10.1016/j.jclepro.2018.10.280

Original publication available at:

https:/ / doi.org/ 10.1016/j.jclepro.2018.10.280

Copyright: Elsevier

http:/ / www.elsevier.com/

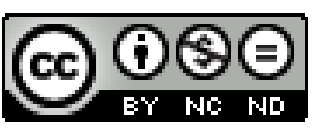




\title{
Extracting key factors for sustainable development of enterprises: Case study of SMEs in Taiwan
}

\author{
Ville Matinaro a , Yang Liu b, c, *, Tzong-Ru (Jiun-Shen) Lee ${ }^{\mathrm{d}}$, Jurgen Poesche ${ }^{\mathrm{a}}$ \\ ${ }^{a}$ Department of Industrial Engineering and Management, Aalto University, 02150 Espoo, Finland \\ b Department of Management and Engineering, Linköping University, SE-581 83 Linköping, Sweden \\ ${ }^{c}$ Department of Production, University of Vaasa, 65200 Vaasa, Finland \\ d Department of Marketing, National Chung Hsing University, Taichung, Taiwan \\ *Corresponding Author: yang.liu@liu.se (Y. Liu)
}

\begin{abstract}
:
In general, enterprises should pay close attention to sustaining sufficient competitiveness in turbulent global business environments that focus on sustainable operations, especially environmental issues. It is obligated for enterprises to protect the environment, utilize sustainable resources and establish eco-industries. Many large enterprises have joined the World Business Council for Sustainable Development (WBCSD). However, the small and medium-sized enterprises (SMEs) pay various degrees of attention to environmental issues and sustainable operations. This paper investigates the sustainable development and innovation of 233 SMEs in Taiwan to find out how to develop a business model that helps them operate in a more sustainable and environmentally friendly way. According to our results, a sustainable business model is a key factor for competitive advantages with straightforward connections to business success. Results also indicate that a sustainable business model is performed with the agreement of colleagues in an organization and it requires comprehensive strategic efforts. This study has limited findings to show the insights of Taiwanese SMEs and should not be generalized in other contexts.
\end{abstract}

Keywords: sustainable business models, key success factors (KFSs), grey relational analysis (GRA), small and medium size enterprises (SMEs)

\section{Introduction}

The objective of this paper is to develop a business model that helps SMEs operate in a more sustainable way. In recent research, discovering sustainable business models (SBMs) has been of great interest to researchers (Boons et al. 2013, Morioka et al. 2016, Rautera et al. 2017, Yang et al. 2017). According to Lozano (2013), there is a need to examine the nature of sustainability drivers and models. Nevertheless, the current literature does not offer a general conceptual definition of sustainable business models (Boons and Lüdeke-Freund 2013). There are also very recent indications that the sustainability approach in organizations could reach beyond the typical value proposal that typical business models have (Lozano et al. 2017) and organizations are increasingly aware of issues such as clean water, energy and pollution when planning their operations (Klemeš et al. 2016, Urbaniec et al. 2017). According to Duić et al. (2015), there is an urgent need for novel sustainability concepts, approaches and methods, including tools which should be developed.

In this paper, we understood sustainable development and sustainability similar to The Brundtland Commission Report (1987) definitions. According to the Brundtland Report on sustainable development, it is defined as development that meets 
the needs of the present without compromising the ability of future generations to meet their own needs (Brundtland 1987). The concept of business models may also need clarification. It seems that that definition of business model is widely discussed among researchers. In general, it seems that the business model concept is understood as a view of the firm's logic for creating and commercializing value or how a company creates and markets value (Osterwalder et al. 2005) According to Teece (2010), the essence of every business model is how it defines a means by which a company delivers value to customers to gain profits, in addition to how it defines a value chain in a way that stakeholders' interests are noticed and customers are willing to pay for it.

Generally, it is accepted that business models consist of at least three vital aspects: value proposition, value creation including delivery and value capture (Morris et al. 2005, Calia, 2007, Johnson et al. 2008, Gambardella et al. 2010, Amit et al. 2010). However, we understood business models and sustainable business models in this paper similar to the ones that Osterwalder et al. (2005) have proposed. Their definition of business model is as follows: “A business model is a conceptual tool that contains a set of elements and their relationships and allows the expression of the business logic of a specific firm. It is a description of the value a company offers to one or several segments of customers and of the architecture of the firm and its network of partners for creating, marketing, and delivering this value and relationship capital, to generate profitable and sustainable revenue streams.” In general, a management system is the way in which an organization manages its business in order to achieve its objectives. The level of complexity of the system will depend on each organization's specific context and can relate to different topics, such as product or service quality, operational efficiency, environmental performance, health and safety in the workplace, etc. Despite several different definitions of management system in this paper, we composed it with an understanding of management systems as ISO 9001, ISO 14001, OHSAS 18001, SA 8000 or similar broadly accepted systems. Researcher such as Fonseca (2015) has highlighted the importance of ISO 14001:2015 certification as an organizational tool for sustainability.

According to Bong et al. (2017), in evolving markets and fast developing countries, there are significant increases in waste where continuous efforts are needed towards cleaner production and clean business models. Wang et al. (2016) argue that increasing public environmental education and providing accessible environmental information are of great importance in societies. Som et al. (2010) continue that technology development must take place in a safe and sustainable manner highlighting life-cycle aspects. It seems that business models with sustainable approaches are highly important for companies and there is a demand in markets for organizations which operate in a sustainable way and produce environmentally friendly products. Caroll et al. (2010) have studied that the wide-ranging view in corporate social responsibility is that corporations benefit from corporate social responsibility (CSR) opportunities. The concept of CSR is grounded on stakeholder theory (Freeman 1984, Clarkson 1995; Donaldson and Preston 1995). Within the stakeholder theory framework corporations have responsibilities towards society and the manager's role is to search for a balance between the needs and demands of multiple stakeholders and not only to serve the interests of shareholders, as supported by a more traditional view of the business (Friedman 1970). There are different definitions of CSR and the concept doesn't have unanimous definition globally. Typically, corporate sustainability, corporate citizenship, ethics and accountability are the cores of CSR concept including the triple bottom line of social, economic and environmental factors.

Sustainable business models seem to be connected to companies' value propositions, value chains and economic models to act according to promises they made to customers and societies. According to Margolis and Walsh (2003), companies 
are progressively requested to offer novel solutions supporting societies to solve human misery in a way that companies can also maximize shareholders' value, as economic theory instructs. They continue by stating that connections of social initiatives, financial performance and development of stakeholder theory should be re-thought in organizations despite the typical approach where social initiatives especially are not seen as being particularly comfortable in companies' economic logic when generating value (Margolis and Walsh, 2003). Bocken et al. (2014) argue precisely that value proposition is essential and can offer measurable social, environmental and economic value. This argument is widely supported in related literature, and according to Weissbrod and Bocken (2017), companies pursue innovation for economic, social and environmental value creation. Henriques et al. (2015) argue that improving economic and ecological efficiency of companies means higher value and competitiveness. Morioka et al. (2016) state that even today there is not sufficient determination and results for global sustainable development set in practice and innovation is vital to make companies transfer beyond traditional models towards sustainable business models.

It is generally agreed that there is a connection between sustainability and company performance. Similarly to several other researchers, Fouts (1997) has found that there is a straightforward positive linkage between environmental performance and economic performance. Orlitzky et al. (2003) have studied in their meta-analysis that there may be greater significance between social and environmental performance and financial performance of companies than is usually is expected. Zhang et al. (2014) state that economic benefits, as well as environmental benefits, can be gained through sustainable approaches. According to Hsu et al. (2017), it has been researched that there are major and positive relationships between corporate social awareness and profitability. They continue that the progress of sustainability management and performance for a corporation is an opportunity for development and growth rather than a threat, emphasizing SMEs. Therefore, finding sustainable business model including factors with other determinants affecting sustainability would be highly useful for organizations. According to Tsai et al. (2009), management systems could be very beneficial to SMEs to gain sustainable competitive advantage. Nevertheless, management systems could be difficult and rather heavy to implement, especially in the context of SMEs' sustainable competitive advantage in turbulent business environment and possible lack of resources (Liu 2013; Liu and Liang 2015).

According to Díaz-García et al. (2015), the concept of eco-innovation is rather new. James (1997) defines eco-innovation as new products and processes which provide customer and business value but significantly decrease environmental impact. Rennings (2000) explains eco-innovation through sustainable development in technological, social and institutional innovation. This statement is supported by Pacheco et al. (2017), arguing that governmental policy must be supportive towards eco-innovation. They continue that accessibility of resources (people, technology, knowledge), awareness of strategic relevance of eco-innovation, technological advisory focused on environment, product and process eco-innovation oriented methods and throughout cooperation with partnership in supply networks are highly supportive governmental policies for SMEs to gain sustainable competitive advantage. Niesten et al. (2016) agree that collaboration among companies, governments and other institutions is central to stimulating transition to a more sustainable society. They continue that alliance advances sustainable benefits by generating legitimacy of sustainable technologies, reducing waste and improving environmental and social performance of firms. Especially the new circular economy (CE) model supports the "reduce, reuse, and recycle" more than "take-make-consume-disposal" approach and the adoption of new business models based on the close-loops of reuse and refurbishment when delivering a higher economic and environmental value (Ghisellini et al. 2016). These aspects can be generalized in different societies globally. 
Especially in the case of SMEs, the governmental policies should have various degrees of supportive considerations to environmental issues and sustainable operations of these potential businesses. According to Almeida et al. (2015) there may be a need for collaboration among governments, industrial segments and companies to accelerate integration of cleaner production into policies and practice. Here, communication is crucial. Domingues et al. (2017) have studied that public sector organisations (PSOs) are lagging in sustainability reporting, but are starting to use sustainability reporting as a communication tool, which could be a highly vital driver for organisational changes towards sustainability. Although Lozano et al. (2016) have studied the fact that companies must find their inner motivation towards sustainability, where a decision to publish sustainability reports, drives sustainability changes in organizations. It seems that when organizations are thriving towards sustainability, internal and external efforts are needed to accomplish this highly valuable common goal.

Summarizing key factors for sustainable development including a sustainable business model (SBM), could be highly useful for SMEs and helpful for the government level when targeting funds or other available resources and regulation of policies. It is obvious that finding out key factors to affect the sustainable development of SMEs is connected to research of key success factors (KSFs). According to Daniel (1961), companies have to achieve at least three to six KSFs to survive and succeed in markets. Daniel's studies are strongly supported by Rockart (1979) given that they argue that if companies want to be competitive, they must be successful with critical success factors that depend on the industry (Rockart, 1979, Bullen and Rockart, 1981). Ramos and Caeiro (2010) have studied the effectiveness of sustainability indicators and found out that stakeholder involvement is an essential factor in sustainability frameworks. These research indications suggest strongly that discovering key success factors of sustainability and forming sustainable business models with stakeholders could be very useful for businesses.

According to Lee et al. (2015), KSFs are variables with respect to characteristics that pertain to one occasion, but not necessarily another occasion. They continue that if an analysis of KSFs is steered, it shouldn't be a description, but instead endorse a more general theory about the study linked to those exact characteristics. According to them, KSFs will lead into four typical research tasks for an empirical analysis: measuring perceived KSFs, finding additional hypotheses about actual causes of value and lower relative costs, measuring how businesses score on potential KSFs and measuring perceived value and relative costs (Lee et al. 2015). As Bullen and Rockart (1981) have stated, finding out exact KSFs in turbulent environments in which companies are operating, will require a mixture of research methods. It seems that seeking KFSs for sustainable development of companies and forming a sustainable business model is a rather complex issue which needs different methods and perspectives to be understood sufficiently.

To research this rather complex issue, grey relational analysis (GRA) is one of the promising perspectives to do so. The GRA method is a quantitative method to measure the importance of various factors, especially when finding out key factors or trends from collected data benefits offered by the GRA method may be valuable, particularly in the case of making analysis and interpretations from collected data sets. Moreover, GRA is a measurement to analyse relevance among discrete sequence data with rather small numbers of collected samples. According to Feng et al. (2004) and Kung et al. (2006), GRA is an accurate means to analyse the relationship between quantified and ordering data even from minor data sets. The difference between GRA and methods such as regression analysis, related analysis or factor analysis is exactly in the accuracy of data sets where these methods are very specific for numbers and styles of sampling compared to the GRA 
method. Deng (1987) argues that GRA doesn't strictly need a certain number of samples, and does not require a typical distribution or assumptions for analysis. Chang et al. (2000) have studied the fact that GRA helps to process with uncertain, multi-variable input, discrete data and non-integrity, compensating for the weaknesses of regression analysis.

For these reasons, GRA has four typical features: models created with GRA are a non-function type of series given that calculation is rather easy to use; it can be calculated based on a small amount of data and data is not subject to comply with any typical distribution. GRA can effectively deal with uncertainty, multivariate input, discrete data and data incompleteness while compensating for disadvantages in statistical regression (Wen et al. 2009). In conclusion, the GRA method can overcome lack that a quantitative indicator can't, especially in reflecting differences between observed factors, which makes results more accurate. In this research, GRA fits well with an objective to extract key success factors for SMEs (Cheng et al. 2017., Wang et al. 2017), especially when researching the best possible sustainable business model based on extracted key success factors. In this research, we use different research methods such as a questionnaire survey and GRA, extracting the most suitable KSFs from SMEs. After revealing KSFs, we suggest a sustainable business model for Taiwanese SMEs as a result of this paper.

\section{Sustainable business models of SMEs in Taiwan}

The objective of this paper is to develop a business model that helps Taiwanese SMEs operate in a more sustainable manner. Nevertheless, through generalization in the research process, this study aims to bring a much more significant contribution concerning sustainable business models in organizations rather than just study Taiwanese SMEs. This is because it seems that this topic is not a commonly researched topic, especially in Taiwanese SMEs. Therefore, researching Taiwanese SMEs could be highly valuable, with possibilities to bring in new contributions to related research of key success factors behind sustainable business models. The relevance of SMEs in the Taiwanese economy is notable, which is illustrated in Table 1.

Table 1: The relevance of SMEs in the Taiwanese economy, extracted from the "White Paper on Small and Medium Enterprises, 2017” (SMEA, 2017). Unit: NT\$ million; thousand; \%

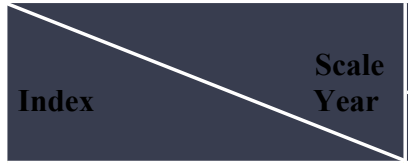

Number

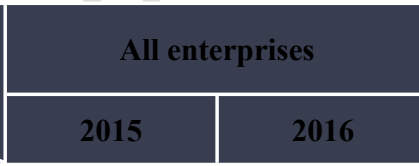

1416738

100

2.21

38875340

100

$-3.39$

29158853

100

$-2.87$

9716487
1440958

100

1.71

38312769

100

$-1.45$

28848507

100

$-1.06$
9464262

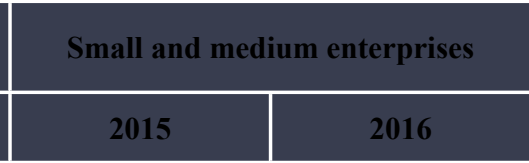

1383981

11803115

10325260
97.69

2.9

30.36

$-0.31$

35.41

$-0.19$

1408313

97.73

1.76

11764677

30.71

$-0.33$

10340886

35.85

0.15

1477855

1423791

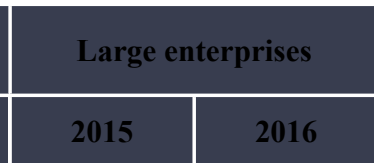

32757

32645

2.31

$-0.97$

$-0.34$

27072225

26548091

69.64

69.29

$-4.68$

18833593

18507621

64.59

64.15

$-4.27$

$-1.73$

8238632

8040471 


\begin{tabular}{|c|r|r|r|r|r|r|}
\hline Ratio & 100 & 100 & 15.21 & 15.04 & 84.79 & -54.96 \\
\hline Annual growth rate & -4.94 & -2.6 & -1.13 & -3.66 & -2.41 \\
\hline Labor Force Employed & 11198 & 11267 & 8759 & 8810 & 1415 & 1432 \\
\hline Ratio & 100 & 100 & 78.22 & 78.19 & 12.64 & 12.71 \\
\hline Annual growth rate & 1.07 & 0.62 & 1.03 & 0.57 & 2.04 \\
\hline Employment & 8860 & 8926 & 6424 & 1.2 \\
\hline Ratio & 100 & 100 & 72.5 & 72.5 & 145 \\
\hline Annual growth rate & 1.41 & 0.74 & 1.49 & 0.75 & 1.99 \\
\hline
\end{tabular}

In this study, we focus on the economic dimension, the social dimension and the environmental dimension of examined organizations. This is because without these rather vital operational aspects and frameworks, organizations cannot truly generate sustainable innovations or give value propositions in a sustainable manner, which is essential for sustainable business models.

Focusing on these three vital aspects of sustainability in organisations is supported in studies of Shen et al. (2016) stating that there are three dimensions in sustainability development: economic prosperity, social welfare, and environmental quality which generally increases human wellbeing. Lozano et al. (2017) argue that if a company has built up a systemic and holistic sustainability framework, it could offer better business models' contribution to sustainability than the ones at presently available by going beyond typical value proposition, value creation and capture-inclusive delivery. Pivato et al. (2008) have studied that corporate social responsibility affects consumer's trust, which turns the actions consumers make into markets. They continue and are supported by research of Surroca et al. (2010) that intangibles mediate the association between corporate responsibility performance and corporate financial performance, and that this mediation operates in equally causal directions. As we have seen, there are commonly accepted drivers towards more sustainable approaches in organizations, but to achieve permanent changes, motivation seems essential. Kris and Law (2010) have studied in their research the fact that key factors affecting sustainable development in organizations can also be internal and begins with management by setting strategies with a sustainability approach. It seems that finding a sustainable business model for SMEs could be very beneficial in general and especially in evolving markets.

Huang et al. (2013) have found that technology, government policy and investments are important assessments that influencing sustainable development in Taiwan. They continue, noting that in Taiwan there are six key factors supporting sustainability in organizations. According to them these factors are establishment of key technological capabilities, degree of integration of relevant laws and regulations, establishment of an industry chain, key raw materials and production equipment, protection of intellectual property and preferential purchase price rates and various subsidies. Their study was supported by Medeiros et al. (2014), stating that critical success factors for environmentally sustainable product innovation are market, law and regulation knowledge; inter-functional collaboration; innovation-oriented learning; and R\&D investments. These issues are highly important to organizations in general and specifically when aiming towards sustainability.

Nevertheless, if there is a lacks in organizational motivation, even if governmental policies are supportive, the path towards sustainable business models could be very rigid. Chen (2008) argues that there is significantly less green intellectual capital in SMEs in Taiwan than large enterprises operating in the same market. As we have seen, throughout collaboration and 
knowledge sharing with the spread of needed information on how to gain benefits and profits through a sustainable mode of operating could be vital. Chen et al. (2006) have studied the fact that performances of green product innovation and green process innovation were positively connected to companies' competitive advantage and investment in the green process and green product innovation was supportive to businesses. Fonseca et al. (2016) have studied that the acceptance of socially responsible policies is a reliable source of competitiveness and the forecasting of long-term success for SMEs. They continue that CSR can be maintained from matched ethical and instrumental viewpoint which they consider as novel information concerning CSR in a non-Anglo-Saxon Country and especially SMEs. They argue that this is significance factor for companies when trying to guarantee long term success through the concept of CSR and by supporting Freeman's (1984) stakeholder theory.

Chen (2008) continues that in Taiwan, SMEs should develop their green core competences to strengthen their green innovation performance and images. It seems that there is a need for adapting sustainable business models and finding out sustainable success factors for organizations to give green value proposals to markets. However, it may be that for SMEs, adapting operations towards sustainable value creation could be difficult if the political environment is not supportive. Martinez-Conesa et al. (2017) have studied the fact that corporate social responsibility is an essential driver instrument for companies to be more innovative, efficient and effective. Our contribution is to provide evidence through research in Taiwanese SMEs proposing a feasible sustainable approach and suggesting a sustainable business model which may be generalized to related organizations globally.

In this research, most activity sectors of the respondents' Taiwanese SMEs are manufacturing and servicing. We analyse these two sectors separately; however, there are no significant differences found from analysing them together. For the numbers of employees and sales volume, the Taiwanese government has formulated clear regulations of SMEs. The definition of SMEs in Taiwan is shown below according to SMEA (2018):

1. Manufacturing, Construction, Mining and Quarrying industries have a paid in capital less than NT\$80 million, or the number of employees is fewer than 200 .

2. The turnover of other industries in the previous year was less than NT\$100 million, or the number of employees is fewer than 100 .

The profiles of respondents are by positions middle- and high-level managers and by gender $50 \%$ male and $50 \%$ female of surveyed organizations.

\section{Methodology}

The objective of this paper is to develop a business model that helps SMEs operate in a more sustainable way. This study has limited findings to show the insights of Taiwanese SMEs and should not be generalized in other contexts. To build up a more complete understanding, we used a case study method and questionaries' to collect empirical evidence from organizations operating in Taiwan. To interpret results, we used GRA to find key sustainable development factors of these organizations. Therefore, we are suggesting rather generalizable conclusions to bring in new contributions to existing theory of sustainable KSFs. Based on our results in economic, environmental and social dimensions including related 
research, we are suggesting a generalizable sustainable business model as strategic sustainable framework for organizations.

In this study we used a case study method because it allows a flexible approach to research, utilizing methods such as questionnaires, use of existing documentation and observation. According to Yin (1981), the case study is a suitable option for examining research questions that seek answers to a phenomenon. This approach emphasizes the use of research approaches such as qualitative research through questionnaires, and interprets with quantitative content analysis. This is especially true when data is collected from real-life context. The methodology used allows observation of the reliability of results generated by the different data collected. We examine the consistency of different qualitative or quantitative data sources from and within the same case using multiple analysts to review the results. The objective is to understand collected data using multiple theoretical perspectives to examine and interpret data. In this study, we use literature review, qualitative questionnaires and we interpret data with the quantitative GRA method (Patton 1999, Denzing 2006).

Sustainability has been a subject of intensive research during recent years. Nevertheless, linking sustainability to actual sustainable operations in organizations is a far less commonly researched topic. According to recent research organizations including SMEs, companies need radical sustainability innovations. It is obvious that companies must open possibilities for constant sustainable development. In here, understanding importance of key sustainable success factors is essential for organizations. Therefore, examining these key success factors of sustainable development and proposing a sustainable business model based on the results is highly essential. The data collection method in this research was interviews with a questionnaire distributed in 233 Taiwanese SMEs. Results from questionnaires were interpreted by GRA. The validity and reliability of data collected can be ensured by improving the required careful documentation of the cases.

The 233 researched SMEs were selected by EMBA of National Chung Hsing University (NCHU) located in Taichung, Taiwan. This is particularly because in this area and its population, SMEs have significant influence in Taiwan, as shown in Table 2. The criterion to choose the specific survey questions and how the survey was validated is supported by the literature review shown in Appendix 10.

Table 2: The significance of SMEs in Taichung, extracted from the "Whitepaper on Small and Medium Enterprises, 2017” (SMEA, 2017). Unit: NT\$ million; \%

\begin{tabular}{|c|c|c|c|c|c|c|c|c|}
\hline Scale City & Total & $\begin{array}{c}\text { Special } \\
\text { Municipalities }\end{array}$ & Taipei City & $\begin{array}{c}\text { New Taipei } \\
\text { City }\end{array}$ & $\begin{array}{l}\text { Taoyuan } \\
\text { City }\end{array}$ & $\begin{array}{l}\text { Taichung } \\
\text { City }\end{array}$ & $\begin{array}{c}\text { Tainan } \\
\text { City }\end{array}$ & $\begin{array}{c}\text { Kaohsiung } \\
\text { City }\end{array}$ \\
\hline \multicolumn{8}{|c|}{ Number } & \\
\hline All enterprises & 1440958 & 1041983 & 233720 & 226133 & 114888 & 190829 & 111733 & 164680 \\
\hline $\begin{array}{l}\text { Small and medium } \\
\text { enterprises }\end{array}$ & 1408313 & 1014819 & 223300 & 221040 & 112083 & 187112 & 109849 & 161435 \\
\hline Ratio & 100 & 72.06 & 15.86 & 15.7 & 7.96 & 13.29 & 7.8 & 11.46 \\
\hline Annual growth rate & 1.76 & 1.87 & 1.39 & 1.93 & 2.59 & 2.6 & 1.7 & 1.24 \\
\hline Large enterprises & 32645 & 27164 & 10420 & 5093 & 2805 & 3717 & 1884 & 3245 \\
\hline \multicolumn{8}{|c|}{ Sale } & \\
\hline All enterprises & 38312768 & 30082001 & 12048958 & 4468150 & 3384878 & 3759269 & 2189079 & 4231667 \\
\hline $\begin{array}{l}\text { Small and medium } \\
\text { enterprises }\end{array}$ & 11764677 & 9060974 & 1931312 & 1937034 & 1232510 & 1726263 & 909878 & 1323977 \\
\hline
\end{tabular}




\begin{tabular}{|c|c|c|c|c|c|c|c|c|}
\hline Ratio & 100 & 77.02 & 16.42 & 16.46 & 10.48 & 14.67 & 7.73 & 11.25 \\
\hline Annual growth rate & -0.33 & -0.34 & 0.03 & -1.08 & 0.49 & 0.12 & -2.22 & 0.16 \\
\hline Large enterprises & 26548092 & 20911980 & 10117646 & 2510701 & 2052013 & 2033007 & 1306759 & 2891855 \\
\hline
\end{tabular}

In order to transfer intangible corporate sustainable development issues into a tangible questionnaire, we divided enterprise sustainable development factors into three levels: economic (A), social (B) and environmental (C) to find key success factors. In each dimension, the significance of samples will increase from left to right in Figures 1, 2 and 3. Founded factors are divided into several groups according to degree of closeness between data in these figures. According to related research, there are approximately three to six key success factors influencing the success of enterprises which are crucial (Daniel, 1961). Therefore, five to six of the most significant factors have been selected from data to be the foundations of a sustainable business model. Collecting data by questionnaires and interpreting data with the GRA method effectively supports the objective of this research. The results of data collection, including literature research, represent strong empirical and quantitative evidence regarding the objective of this paper.

By using the GRA method, we find out the differences of sustainable development factors of enterprises via the operating environments of these organizations. These differences are the size of markets, differences in management practices and available resources in use. After that, we extract key factors of sustainable development of SMEs through the questionnaires and compare these factors to different degrees of attention. Through the case study, we analyse whether there are different elements in the factors for sustainable development of enterprises, under different culture backgrounds and different industrial sectors. The results of this paper can help summarize key factors for sustainable development by suggesting which kind of sustainable business model can be built for SMEs and other organizations in general.

\section{Extracting the key factors of sustainable business models of SMEs}

The objective of this paper is to develop a business model that helps SMEs operate in a more sustainable way. The result of this research can be seen from Table 3, where extracted key success factors are divided into three dimensions: the economic dimension (A), the social dimension (B) and the environmental dimension (C). These key success factors will be determinants of a business model that helps SMEs operate in a more sustainable way. The calculation process is only presented in the economic dimension and it is done in the same way when calculating results for other dimensions as well.

\subsection{The economic dimension}

In the economic part of this paper we are finding out factors in the economic dimension for a sustainable business model using the Likert scale as evaluation criteria in our questionnaire. A score of one indicates an answer in strong disagreement with a given statement and a score of five indicates strongly agreement. We used responses with a score of five as a reference sequence in the following manner: $\left(\mathrm{x}_{0}=\left\{\mathrm{x}_{0}(1), \mathrm{x}_{0}(2), \ldots, \mathrm{x}_{0}(\mathrm{k})\right\}\right)$. The original data of the questionnaire is regarded as a comparative sequence as follows: $\left(\mathrm{x}_{\mathrm{i}}=\left\{\mathrm{x}_{\mathrm{i}}(1), \mathrm{x}_{\mathrm{i}}(2), \ldots, \mathrm{x}_{\mathrm{i}}(\mathrm{k})\right\}\right)$, in which $\mathrm{x}_{\mathrm{i}}(\mathrm{k})$ is the score given by respondents to the $\mathrm{k}$ question in the $\mathrm{i}$ questionnaire. Besides, the difference between a reference sequence and a comparative sequence is called a difference sequence. If its value is small, the reference sequence and the comparative sequence are closer to each other with higher relevance. In this research, the comparative sequence data of the original data is shown in Appendix 1. Moreover, the steps of the GRA are as follows: 
Step 1. The calculation of difference between comparative sequence and reference sequence (i.e., scores of five, which indicate strong agreement). A value of difference sequence is defined as the absolute difference value between the comparative sequence and the reference sequence as follows in Equation 1

Equation 1

$$
\Delta_{0 i}(k)=\left|x_{0}(k)-x_{i}(k)\right|
$$

and difference sequence results are as in Appendix 2. According to the difference sequence value in Appendix 2 and when the identification coefficient $(\zeta)$ is 0.5 , the grey relational coefficient $\mathrm{r}\left(\mathrm{x}_{0}(k), \mathrm{x}(k)\right)$ can be obtained. Here, $\Delta \min$ and $\Delta \max$ refer to the minimum and maximum difference sequence value of the $\mathrm{k}$ item as in equation 2, and the results are as shown in Appendix 3.

Equation 2

$$
r\left(x_{0}(k), x_{i}(k)\right)=\frac{\Delta \min +\zeta \Delta \max }{\Delta_{0 i}(k)+\zeta \Delta \max }
$$

Step 2. After the grey relational coefficient shown as $\mathrm{r}(\mathrm{x} 0(k), \mathrm{x} i(k))$ is obtained, we calculate the average value of each questionnaire material to obtain a grey relational coefficient $(\mathrm{r}(\mathrm{x} 0, \mathrm{x} i))$ of each questionnaire item in Table 4 (as shown in Appendix 1). Arranging value of grey relational coefficient from large to minor form grey relational sequence is done just as in Equation 3 so that it can be known precisely which factors are important in the economic dimension of the sustainable business model.

Equation 3

$$
r\left(x_{0}, x_{i}\right)=\frac{1}{n} \sum_{k=1}^{n} r\left(x_{0}(k), x_{i}(k)\right)
$$

Then, we convert grey relational value results in the economic dimension (Appendix 1 and 2). The results contain eight groups shown in Appendix 7. As we can see from Figure 1, the first group contains only one factor with high significance at the end of the scale. The second group contains four factors and a third group contains two factors. These three groups contain seven of the most significant factors. According research presented in this paper, we have chosen five to six of the most significant factors of all groups representing key success factors of a sustainable business model. These are A8 (0.7568), A7 (0.7411), A15 (0.7353), A10 (0.7336), A9, 0.7251) as shown in Table 3.

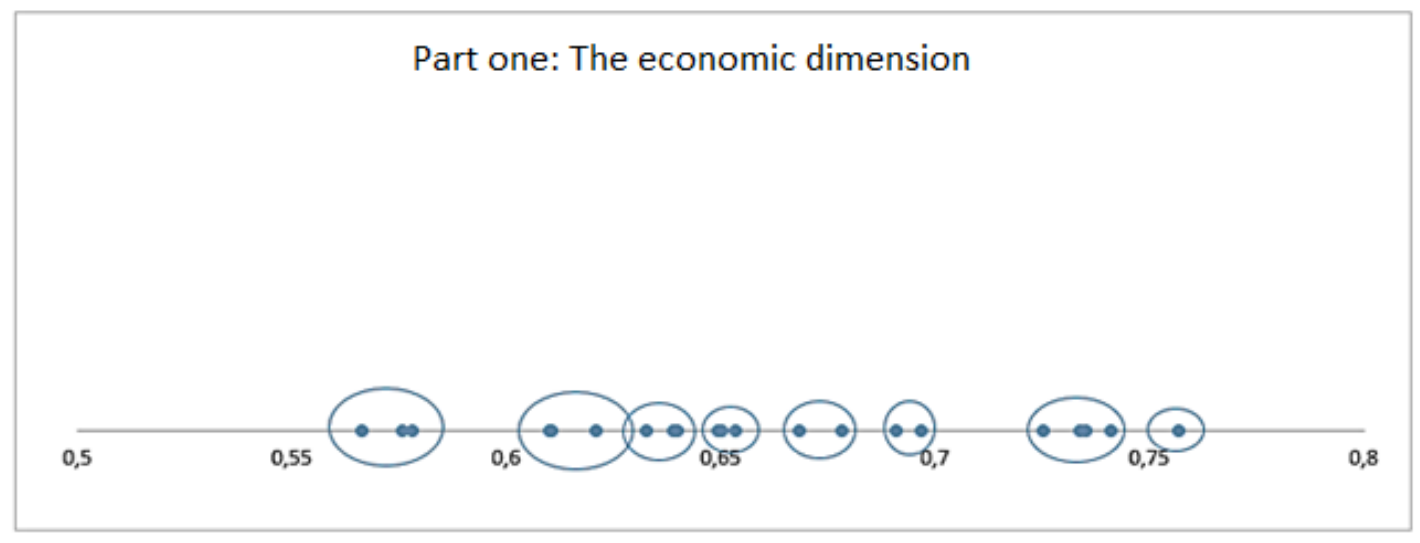

Figure 1. Numerical graph of grey relational value in the economic dimension 
When examining respondents from the economic dimension, it was found that the following factors are the most attractive for a sustainable business model: profit, cost reduction, competitiveness, brand value, added value, decision-making, resource allocation and financial aspects.

\subsection{The social dimension}

In the social part of this paper, we are finding out factors at in the social dimension for a sustainable business model. The extraction process is similar, as demonstrated earlier in this paper. Comparative sequence and reference sequence are established to obtain differential value between two of the recognition coefficients $(\zeta)$ at 0.5 to calculate the value of the recognition coefficient $(\gamma)$. After the average value is obtained, the grey relational coefficient can be obtained. The arrangement of the grey relational coefficient to obtain grey relational order is expressed in numerical lines and closeness between data. If closeness is significant, they are regarded as being in the same group and are chosen as the most important factors.

In Appendix 5 is represented grey relational degree and grey relational order of the social dimension. The numerical values after analysis are converted to the numerical graphs shown in Figure 2. Each point represents a question, and significance increases from left to right. Here, regarding closeness and the difference between spots, data can be divided into sub-groups. The results contain seven groups shown in Appendix 8. As we can see from Figure 2, the first group contains two factors with high significance at the end of the scale. The second group contains three factors and third group also contains three factors. These three groups contain eight of the most significant factors. According to the research presented, we have chosen five to six of the most significant factors of all groups representing key success factors of sustainable business models from the social dimension. These are B8 (0.7693), B13 (0.7669), B16 (0.7595), B11 (0.7622) and B18 (0.7574), as shown in Table 3.

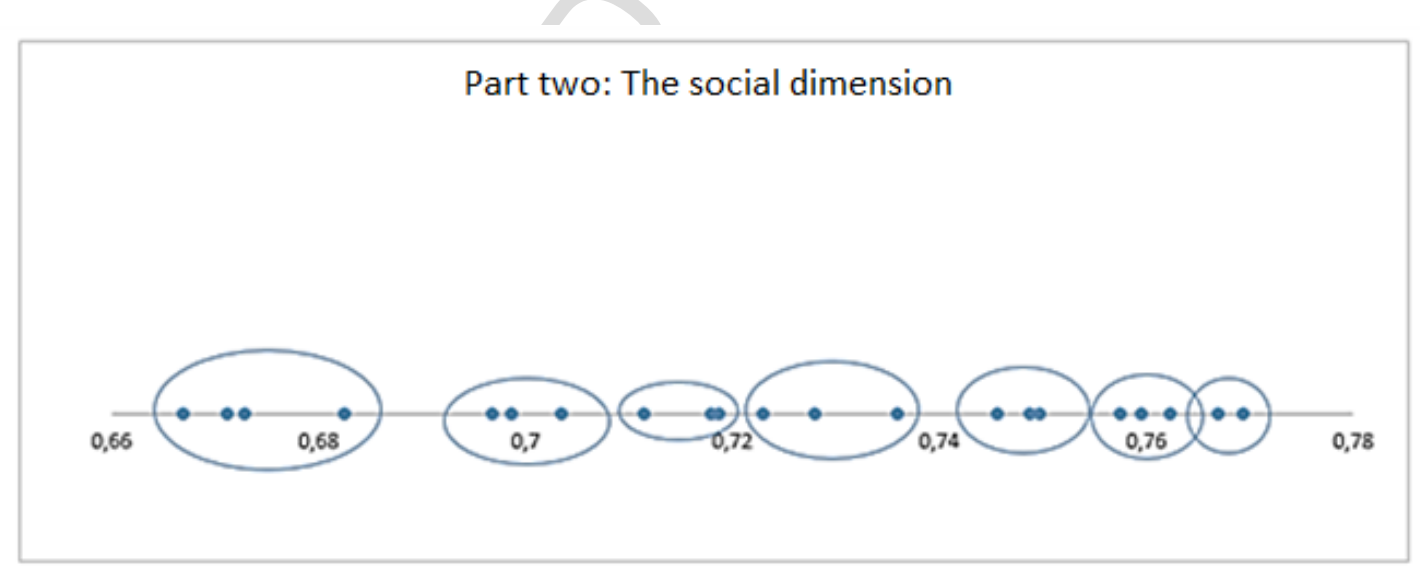

Figure 2. Numerical graph of grey relational value in the social dimension

After exploring respondents from the social dimension, it was found that the following factors are the most attractive for a sustainable business model: internal staff views on the enterprise, an external view of the enterprise, and the need to be transparent publicly.

4.3 The environmental dimension 
In the environmental part of this paper, we uncover factors in the environmental dimension for a sustainable business model. The extraction process is parallel, as demonstrated before. Appendix 6 depicts grey relational degree and grey relational order of the environmental dimension. The numerical values after analysis are converted to the numerical graphs shown in Figure 3. Each point represents a question and significance increases from left to right. According to the closeness and difference between spots, data can be further divided into sub-groups. The results contain the six groups shown in Appendix 9. As we can see from Figure 3, the first group contains one factor with high significance at the end of the scale. The second group contains three factors and in the third group, there are three factors as well. These three groups contain the seven most significant factors. According to the research presented, we have chosen five to six of the most significant factors of all groups representing the key success factors of a sustainable business model in the environmental dimension. These are: C17 (0.7714), C9 (0.7436), C16 (0.7369), C7 (0.7339), C2 (0.7251) and C18 (0.7168), as shown in Table 3.

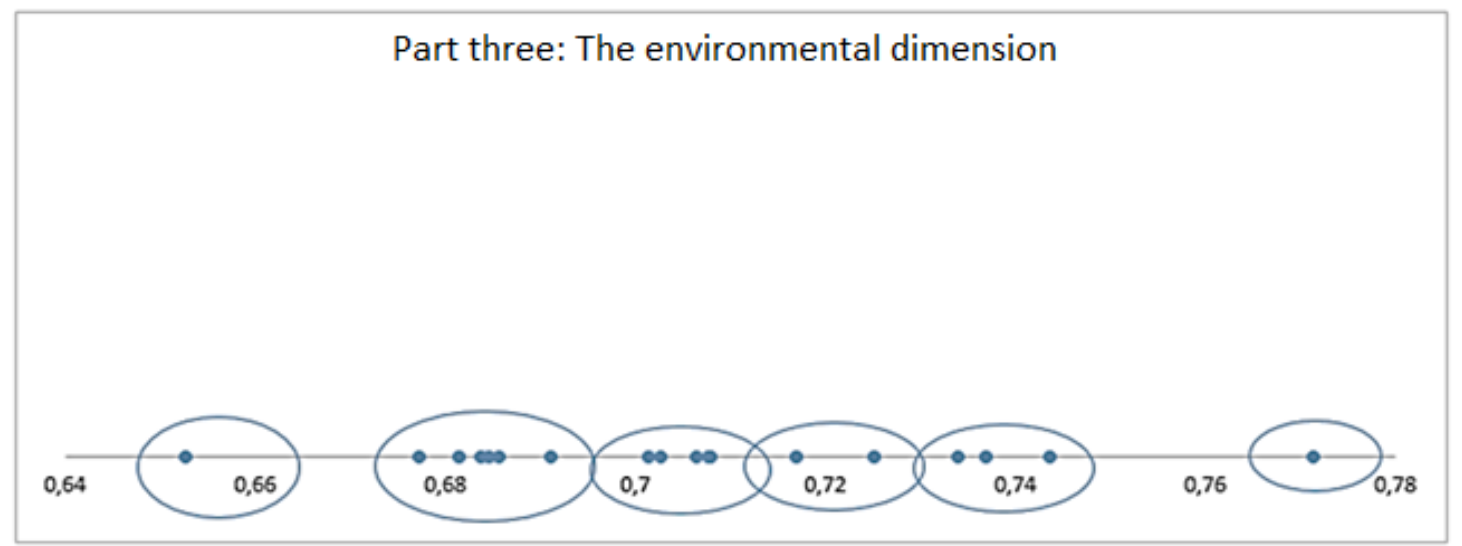

Figure 3. Numerical graph of grey relational value in the environmental dimension

After investigating respondents from the environmental dimension, it was found that the following factors are the most attractive for a sustainable business model: ecological environment, climate change, impact of products and efficiency of enterprises' sustainable development.

\subsection{Summarizing results from GRA}

According to results from GRA, the most important factors of economic, social and environmental dimensions are extracted and summarized in Table 3. These extracted factors are at the core of our suggestion for sustainable business model that helps small and medium-sized enterprises to operate in a more sustainable manner in Taiwan.

Table 3: Key factors of a sustainable business model for Taiwanese SMEs

\begin{tabular}{|c|c|c|}
\hline Economic dimension & Social dimension & Environmental dimension \\
\hline \hline $\begin{array}{c}\text { A8 A sustainable business model } \\
\text { establishes competitive advantage. }\end{array}$ & $\begin{array}{c}\text { B8 A sustainable business } \\
\text { model can show } \\
\text { corporate value }\end{array}$ & $\begin{array}{c}\text { C17 The quality of a sustainable } \\
\text { business model is strictly } \\
\text { controlled through continuous } \\
\text { improvement }\end{array}$ \\
\hline
\end{tabular}




\begin{tabular}{|c|c|c|}
\hline $\begin{array}{c}\text { A7 A sustainable business model } \\
\text { promotes an enterprise's } \\
\text { competitive position }\end{array}$ & $\begin{array}{c}\text { B13 The operation of a } \\
\text { sustainable business } \\
\text { model requires an } \\
\text { enterprise to put in a lot } \\
\text { of effort }\end{array}$ & $\begin{array}{c}\text { C9 A sustainable business model is } \\
\text { made up of many measurements. }\end{array}$ \\
\hline $\begin{array}{c}\text { A15 A sustainable business model has } \\
\text { a positive contribution to the } \\
\text { other business operations of the } \\
\text { company }\end{array}$ & $\begin{array}{c}\text { B11 The operation of a } \\
\text { sustainable business } \\
\text { model has a positive } \\
\text { impact on a company's } \\
\text { reputation }\end{array}$ & $\begin{array}{c}\text { C16 A sustainable business model is } \\
\text { considered to be suitable in } \\
\text { natural environment protection }\end{array}$ \\
\hline $\begin{array}{c}\text { A10 A sustainable business model } \\
\text { promotes an enterprise's image } \\
\text { in the market }\end{array}$ & $\begin{array}{c}\text { B16 A sustainable business } \\
\text { model is established on } \\
\text { sustainable operation of } \\
\text { the enterprise }\end{array}$ & $\begin{array}{c}\text { C7 A sustainable business model } \\
\text { involves comprehensive strategic } \\
\text { efforts from companies }\end{array}$ \\
\hline $\begin{array}{c}\text { A9 A sustainable business model is } \\
\text { the key factor for business success }\end{array}$ & $\begin{array}{c}\text { B18 A sustainable business } \\
\text { model is carried out } \\
\text { with the agreement of } \\
\text { all colleagues of a } \\
\text { company. }\end{array}$ & $\begin{array}{c}\text { C2 A sustainable business model } \\
\text { takes into consideration the } \\
\text { factors that affect the ecological } \\
\text { environment. }\end{array}$ \\
\hline & a & $\begin{array}{c}\text { C18 A sustainable business model is } \\
\text { a continuous process. }\end{array}$ \\
\hline
\end{tabular}

\section{Discussion}

The objective of this paper is to develop a business model that helps SMEs operate in a more sustainable manner. We develop a business model based on founded key factors in three vital dimensions of every organization, economic, social and environment dimension. These key indicators of presented dimensions of sustainable development of SMEs are presented in Table 3 and based on these results, we formed a sustainable business model presented in Figure 4 .

\section{Sustainable business model}

\section{Economic dimension}

Establishing throughout economic sustainability strategy from management where gaining profits are connected to sustainable operations in organization.

Through strategy and proposals of sustainable operations, an organization can demand higher price from the markets, gain competetive advantages, shareholder value including increasing business success.

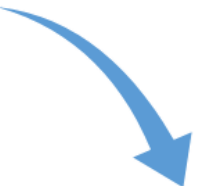

Environmental dimension

To gain internal motivation and external significance in the marketplace, an organization should establish sustainability reporting.

Sustainability is equal to environmental quality, where an organization must agreed to act in a sustainable way and put effort into it, especially management.

By providing sustainable proposals, an organization can display their corporate values in the marketplace and gain a positive reputation.

An organization's internal motivation is essential and can Sustainable value proposition through organizational strategy. Sustainable value creation through economical, social and environmental acts in organization.

Sustainable delivery as promised to markets, customers and shareholders. Sustainable value capture through sustainable strategy increasing organizational value and profits. 
Figure 4. Our suggestion of a sustainable business model for Taiwanese SMEs

We extracted these five to six indicators in each dimension according to research of Daniel (1961) and Bullen and Rockart (1981) and related studies presented earlier in this paper. According to results in the economic dimension, a sustainable business model is clearly seen as a key factor for competitive advantages, positioning in the markets and it is conclusively vital for business success having a positive contribution to the whole organization and promoting enterprises' image in the market. This finding is highly interesting because of research implications that companies do not innovate enough to transfer beyond traditional models towards sustainable business models and products (Medeiros et al. 2014). According to our results, in the economic dimension there should be plenty of interest in organizations to develop sustainable business models and it seems there are direct connections between business success and consumer behaviour, as has been shown by researchers such as Pivato et al. (2008), Henriques et al. (2015) and Weissbrod and Bocken (2017).

In the social dimension, results indicate that a sustainable business model is performed with the agreement of colleagues of the companies and it requires enterprises to put a lot of efforts in it as an organization. A conclusively sustainable business model can show corporate value, has a positive impact on a company's reputation in the market and should establish actual sustainable operation of the enterprise. In the environmental dimension, results show us that a sustainable business model involves comprehensive strategic efforts from companies, should take into consideration the factors that affect the ecological environment and is strictly controlled through continuous improvement and processes in organizations. Therefore, a sustainable business model is considered to be suitable in natural environment protection and made up of several measurements with high significance in societies. According to these results, in the social and environmental dimensions, communication, reporting, motivation and collaboration are crucial between public sector and private sector organizations, including society. This argument is supported in recent research and by researchers like Niesten et al. (2016), Domingues et al. (2017) and Wang et al. (2016).

As we have seen that the concept of CSR is grounded on stakeholder theory as several researches has shown us (Freeman 1984, Clarkson, 1995; Donaldson and Preston, 1995). There are also implications that when SMEs are trying to guarantee long term business success it can be done through the concept of CSR and by supporting stakeholder theory (Fonseca et al. 2016). The perspective to business success may need more coherent understanding from ethical and instrumental point of view which does not close off each other. As Ghisellini et al. (2016) have studied, the new concept of the circular economy could bring in new contributions on how to organizations should built up their business models in future. One of our results is that SMEs need through economic sustainability strategy with sustainable value proposals to act in a sustainable way and to gain more profits by doing so. In our perspective it means that coherent sustainable business models for organizations should be built through sustainability strategy in a way where CSR, CE and stakeholder theory are taken into account.

One result of this study is suggesting that the economic importance of sustainable business model is essential for SMEs and other organizations, which is supported widely in the research presented. As we have seen from the studies of Fouts (1997), Orlitzky et al. (2003), Chen et al. (2006), Zhang et al. (2014), Bocken et al. (2014), Henriques et al. (2015) and Lozano et al. (2017) that there may be straightforward linkage between sustainability, business performance and gaining of profits, including the suggestion that the sustainability approach in business models could even reach beyond the typical value proposal that organizations have. This argument is supported by studies of Margolis and Walsh (2003), which argue 
that social initiatives and re-thinking typical economic logic may open new possibilities for the financial performance of companies. This could mean that there may be undiscovered possibilities for organizations to gain profits by providing high sustainable value proposals to markets against higher profits through a sustainable approach to operating. This might be highly valuable for societies, the environment and organizations if they understand this matter correctly as Caroll et al. (2010) have shown us. As we have seen recently in the automobile industry, there is absolutely no room for loss of reputation in sustainable issues, especially in developed countries.

As researchers such as Kris and Law (2010), Huang et al. (2013), Shen et al. (2016) and Morioka et al. (2016) have stated, establishing a sustainable business model requires motivation in organizations, including the right kind of governmental policies. These actions could lead to sustainable approaches in organizations worldwide including Taiwanese SMEs to help them gain more profitable growth and at the same time support countries in their societal change towards more environment friendly societies. There are also research suggestions that the literature does not offer a general conceptual definition of sustainable business models (Boons and Lüdeke-Freund 2013). Nevertheless, the model proposed in this paper aims to help Taiwanese SMEs to operate in a more sustainable manner.

\section{Conclusions}

In recent discussions, organizations are increasingly worried about their own actions towards a sustainable approach to operating with eagerness to resolve what they must do to operate in a more sustainable way. This can be seen in several debates by top leaders, but very recently pure water, energy and pollution seem to be increasingly important issues for organizations. It looks like there is a need in organizations to act in a highly sustainable way and discover a business model which makes it most suitable for them to do so. In represented research, there are indications which suggest that if organizations provide sustainable value propositions to customers, customers are willing to pay more for their goods or services. This may mean higher profits for organizations. For example, in the construction sector, customers are increasingly aware of the sustainability of buildings, production methods that are sustainable and are ready to pay more to ensure the sustainable life cycle of properties. Especially in this kind of highly important industrial sectors for environment, sustainable business models should be built up in a way where CSR, CE and stakeholder theory are taken into account and considered as key strategy for business success.

According to our results, it seems that a sustainable business model is a key factor for competitive advantages with rather straightforward connections to business success. Results also indicate that a sustainable business model is performed with the agreement of colleagues in an organization and it requires comprehensive strategic efforts. It should be strictly controlled through continuous improvement and processes in organizations with collaboration between the public and private sector. In this research, we are arguing that organizations should renew their sustainable value proposals and form a sustainable business model through key success factors in economic, societal and environmental dimensions represented in Table 3 and Figure 4. Moreover, this means that sustainability must be seen as a key part of the strategy of every organization. When organizations believe that they can gain more profits, better competitive advantages including better shareholder value and at the same time a positive image in the marketplace, there is real economic significance, drivers and motivation in organizations to act in a sustainable manner. This also means that organizations must keep their sustainable value propositions including promises for societies and notice that it may prove costly to cheat. 
This kind of development will need support from governmental policies and legalisation which increases organizations' motivation towards sustainability. This is highly important, especially in the case of SMEs or start-ups which operate in turbulent environments and where sustainability may not be the key objective if they are struggling to survive. If governments can support a sustainable manner of operating with legalisation which considers the needs of SMEs and other organizations, it could be a highly relevant matter, especially in evolving markets which could suffer environmental hazards. In this kind of environment, there could even be plenty of demand hiding in markets which may lead to business success of organizations if they can provide sustainable value propositions and really stand up for them.

When we discuss a matter such as sustainability, it seems to be a win-win situation for all parties. If research can point out what kind of sustainable business framework could lead to the success of organizations and organizations can form sustainable business models according to research, it is highly valuable for societies and the environment. It looks like this aim can be achieved with governmental cooperation, even in a way which can generate more profit for organizations that are committed to this kind of development. Development of collaboration and communication through commonly accepted reporting between private and public-sector organizations could be highly vital and a driver towards adapting sustainable development and business models generally. These kinds of actions could also increase inner motivation in organizations to drive towards developing sustainable business models.

This research has highlighted which kind of key factors are essential to create sustainable business models for SMEs in Taiwan. Nevertheless, we hope that this research can bring about new contributions to sustainability and convey how to form sustainable business models. In the future, we hope to see extensive research around this important issue especially in non-Anglo-Saxon countries and other cultural contexts of SMEs. Particularly studies which try to find out what kind of value propositions beyond ordinary ones could be possible through sustainable business models, which kind of sustainable business models are the most effective for organizations and how organizations can generate more profits through sustainability would be highly welcome. Research which are trying to find connecting factors of CSR, stakeholder theory and business success, as well as investigating the role of regulators in the sustainable development of societies and organizations operating in these societies is highly essential. 


\section{References}

Almeida, C.M.V.B., Agostinho, F., Giannetti, B.F., Huisingh, D. (2015). Integrating cleaner production into sustainability strategies: an introduction to this special volume. Journal of Cleaner Production, 96(2015):1-9.

Amit, R., Zott, C. (2001). Value creation on e-business. Strategic Management Journal 22(6-7):493-520.

Bocken, N.M.P., Short. S.W., Rana, P., Evans. S. (2014). A literature and practice review to develop sustainable business model archetypes. Journal of Cleaner Production 65(15 February 2014): 42-56.

Bong, C.B.C., Lim, L.Y., Ho, W.S., Lim, J.S., Klemeš, J.J., Towprayoon, S., Ho, C.S., Lee, C.T. (2017). A review on the global warming potential of cleaner composting and mitigation strategies. Journal of Cleaner Production, 146(10): 149157.

Boons, F., Lüdeke-Freund, F. (2013). Business models for sustainable innovation: state-of-the-art and steps towards a research agenda. Journal of Cleaner Production, 45 (April 2013): 9-19.

Boons, F., Montalvo, C., Quist, J., Wagner, M. (2013). Sustainable innovation, business models and economic performance: an overview. Journal of Cleaner Production. 45(2013):1-8.

Bullen, C. V., Rockart, J. F. (1981). A primer on critical success factors. Cambridge, MA: Centre for Information Systems Research, MIT.

Brundland, G.H. (1987). World Commission on Environment and Development: Our common future. Oxford: Oxford University Press.

Calia, R.C., Guerrini, F.M., Moura. G.L. (2007). Innovation networks: From technological development to business model reconfiguration. Technovation. 27(8):426-432.

Caroll, A.B., Shabana, K.M. (2010). The Business Case for Corporate Social Responsibility: A Review of Concepts, Research and Practice. International Journal of Management Reviews, 12(1), pp. 85-105.

Clarkson, M. (1995), A stakeholder framework for analysing and evaluating corporate social performance", Academy of Management Review, 20, 92-117.

Chang, W. C., Wen, K. L., Chang, T. C. (2000). Methods and application of grey relational model. Taipei: Gau Lih.

Chen, YS. (2008). The Driver of Green Innovation and Green Image - Green Core Competence. Journal of Business Ethics. 81(3):531-543.

Chen, YS. (2008). The Positive Effect of Green Intellectual Capital on Competitive Advantages of Firms. Journal of Business Ethics 77(3):271-286.

Chen, YS., Lai, SB., Wen, CT. (2006). The Influence of Green Innovation Performance on Corporate Advantage in Taiwan. Journal of Business Ethics. 67(4):331-339. 
Cheng, L., Ren, J. 2017. Multi-attribute sustainability evaluation of alternative aviation fuels based on fuzzy ANP and fuzzy grey relational analysis. Journal of Air Transport Management: Available online 14 October 2017 In Press, Corrected Proof.

Daniel, D. W. (1961). Management information crisis. Harvard Business Review, 39(5):111-121.

Denzin, N. (2006). Sociological Methods: A Sourcebook. Aldine Transaction. ISBN 978-0-202-30840-1. (5th edition).

Deng, J. (1987). The Basic methods of grey system. Wuhan: Huazhong University Publishing House.

Díaz-García, C.; González-Moreno, Á.; Sáez-Martínez, F. J. (2015). "Eco-innovation: insights from a literature review". Innovation: Management, Policy \& Practice. 17(1): 6-23.

Domingues, A.R., Lozano, R., Ceulemans., K., Ramos, T.B. (2017). Sustainability reporting in public sector organisations: Exploring the relation between the reporting process and organisational change management for sustainability. Journal of Environmental Management, 192(1):292-301.

Donaldson, T. and Preston, L. (1995), "The stakeholder theory of the corporation: concepts, evidence and implications", Academy of Management Review, 20, 65-91.

Duić, N., Urbaniec, K., Huisingh, D. (2015). Components and structures of the pillars of sustainability. Journal of Cleaner Production, 88(1):1-12.

Feng, C. M., Chiou, Y. C. (2004). Research and analytical methods. Taipei: Chien-Tu Cultural Enterprise Company.

Fonseca, L., Ferro, R. (2016). Does it Pay to be Social Responsible? Portuguese SMEs feedback. Intangible Capital, 12(2), pp. 487-505.

Fonseca, L. (2015). ISO 14001:2015. An improved tool for sustainability. Journal of Industrial Engineering and Management 8(1). DOI: http://dx.doi.org/10.3926/jiem.1298.

Fouts, P.A. (1997). A Resource-Based Perspective On Corporate Environmental Performance And Profitability. Academy of Management. 40(3):534-559.

Ghisellini, P., Cialani, C. and Ulgiati, S. A review on circular economy: the expected transition to a balanced interplay of environmental and economic systems. J. Clean. Prod. 2016. 114, 11-32. doi: 10.1016/j.jclepro.2015.09.007.

Freeman, R.E. (1984). Strategic management: A stakeholder approach. Boston: Pitman.

Friedman, M. (1970) 'The social responsibility of business is to increase its profits', New York Times Magazine, 13 September.

Gambardella, A., McGahan, A.M .(2010). Business model innovation: General purpose technologies and their implications for industry structure. Long Range Planning. 43(2-3):262-271. 
Henriques, J., J,Catarino. (2015). Sustainable Value and Cleaner Production - research and application in 19 Portuguese SME. Journal of Cleaner Production. 96(1):379-386.

Huang, W.C., Jhong C.H., Ding, J.F.(2013). Key Factors Influencing Sustainable Development of a Green Energy Industry in Taiwan. Mathematical Problems in Engineering Volume. Article ID 791896, 10 pages.

Hsu, C.-H., Chang, A.-Y., Luo, W. (2017). Identifying key performance factors for sustainability development of SMEs integrating QFD and fuzzy MADM methods. (2017). Journal of Cleaner Production. 161(10 September 2017):629-645.

Johnson, M.W., Christensen, C.C., Kagermann, H. (2008). Reinventing your business model. Harvard Business Review. 86(12):50-59.

Klemeš, J. J., Varbanov, P.S., Lam, H.L., Yusup, S. (2016). Energy, Water and Environmental Footprint Interactions: Implications for the major economy sectors of Europe, South East Asia and Worldwide. Procedia Engineering, 148(0): 1199-1250.

Kris, M., Y, Law. (2010). Factors Affecting Sustainability Development: High-Tech Manufacturing Firms in Taiwan. Asia Pacific Management Review 15(4) 619-633.

Kung, C. Y., Yang, P. Y. (2006). Applying grey relational analysis to quality function deployment process - A case study of middle medical centers. The 11th Grey Theory and Applications Conference (pp. 7-9), Hsinchu.

Lee, T.R., Lin, S.H., Liu, Y., Imeri, S. (2015). Key success factors for implementing Taiwan TrainQuali System (TTQS) in Taiwanese enterprises. Production \& Manufacturing Research. 3(1):84-102.

Liu, Y. (2013). Sustainable competitive advantage in turbulent business environments. International Journal of Production Research, 51(10):2821-2841.

Liu, Y., Liang, L., (2015). Evaluating and developing resource-based operations strategy for competitive advantage: an exploratory study of Finnish high-tech manufacturing industries. International Journal of Production Research, 53(4):1019-1037.

Lozano, R., Masachika, S.,Carpenter, A., Tyunina, O. (2017). An Analysis of the Contribution of Japanese Business Terms to Corporate Sustainability: Learnings from the " Looking-Glass " of the East. Sustainability 9(188):1-17.

Lozano, R., Nummert, B., Ceulemans, K. (2016). Elucidating the relationship between Sustainability Reporting and Organisational Change Management for Sustainability, Journal of Cleaner Production. 125(1 July 2016):168-188.

Lozano, R. (2013). A Holistic Perspective on Corporate Sustainability Drivers. Corporate Social Responsibility and Environmental Management 22(1):32-44.

Margolis, J.D. and Walsh, J.P. (2003). Misery loves companies: social initiatives by business. Administrative Science Quarterly, (48), pp. 268-305. 
Martinez-Conesa, I., Soto-Acosta P. Palacios-Manzano, M. 2017. Corporate social responsibility and its effect on innovation and firm performance: An empirical research in SMEs. Journal of Cleaner Production. (142), pp. 2374-2383.

Medeiros, J.F., Ribeiro, J.L.D., Cortimiglia, M.N. (2014). Success factors for environmentally sustainable product innovation: a systematic literature review. Journal of Cleaner Production. 65(15 February 2014):76-86.

Morioka, S.N., Evans, S., Monteiro de Carvalho, M. (2016). Sustainable Business Model Innovation: Exploring Evidences in Sustainability Reporting. Procedia CIRP, 40(2016): 659-667.

Morris, M., Schindehutte, M., Allen, J. (2005). The entrepreneur's business model: Toward a unified perspective. Journal of Business Research. 58(6):726-735.

Niesten, E., Jolink, A., Beatriz Lopes de Sousa Jabbour, A., Chappin, M., Lozano, R (2016). Sustainable collaboration: The impact of governance and institutions on sustainable performance. Journal of Cleaner Production, 155(2):1-6.

Osterwalder, A.; Pigneur, Y.; Tucci, C. L. (2005) "Clarifying Business Models: Origins, Present, and Future of the Concept," Communications of the Association for Information Systems, 16 (1): 1-25.

Orlitzky, M., Schmidt, F., Rynes, S., (2003). Corporate social and financial performance: a meta analysis. Organizations Studies. 24 (3), 403-441.

Pacheco, D.A.D.J., Ten Caten, C.S., Jung, C.F., Ribeiro, J.L.D., Navas, H.V.G., Cruz-Machado, V.A.(2017). Eco-innovation determinants in manufacturing SMEs: Systematic review and research directions. Journal of Cleaner Production 142(4):2277-2287.

Patton, MQ. (1999). Enhancing the quality and credibility of qualitative analysis. HSR: Health Services Research. 34(5): 1189-1208

Pivato, S., Misani, N. and Tencati, A. (2008). The impact of corporate social responsibility on consumer trust: the case of organic food. Business Ethics: A European Review, (17), pp. 3-12.

Ramos, T.B., Caeiro, S. (2010). Meta-performance evaluation of sustainability indicators. Ecological Indicators, 10(2):157166.

Rautera, R., Jonkerb, J., Baumgartnera, R.J. (2017). Going one's own way: drivers in developing business models for sustainability. Journal of Cleaner Production. 140(1):144-154.

Rennings, K. (2000). "Redefining innovation - eco-innovation research and the contribution from ecological economics". Ecological Economics. 32(2):319-332.

Rockart, J. F. (1979). Chief executives define their own data needs. Harvard Business Review, 57(2):81-93.

SMEA (2017). "White Paper on Small and Medium Enterprises in Taiwan, 2017”, Small and Medium Enterprise Administration, Ministry of Economic Affairs, Taiwan, R.O.C. 
SMEA (2018). "The identification standards for Small and Medium Enterprises" (in Chinese). Small and Medium Enterprise Administration, Ministry of Economic Affairs, Taiwan, R.O.C.

URL: https://www.moeasmea.gov.tw/ct.asp?xItem=672\&ctNode=21

Som, C., Berges, M., Chaudhry, Q., Dusinska, M., Fernandes, T.F., Olsen, S.I., Nowack, B. (2010). The importance of life cycle concepts for the development of safe nanoproducts. Toxicology, 269(2-3):160-169.

Surroca, J., Tribo Jorep, A., Waddock, S., 2010. Corporate responsibility and financial performance: the role of intangible resources. Strategic. Management. Journal, 31(5), pp. 463-490.

Shen, L., Zhang, Z., Zhang, X., Yan, H., He, B. (2016). Measuring incoordination-adjusted sustainability performance during the urbanization process: Spatial-dimensional perspectives, Journal of Cleaner Production, 147(1 February 2017):731734.

Teece, D.J. (2010). Business Models, Business Strategy and Innovation. Long Range Planning, 43(2-3):172-194.

Tsai, W.H., Chou, W.C. (2009). Selecting management systems for sustainable development in SMEs: A novel hybrid model based on DEMATEL, ANP, and ZOGP. Expert Systems with Applications. 36(2):1444-1458.

Urbaniec, K., Mikulčićb, H., Rosenc., M.A., Duićb, N .(2017). A holistic approach to sustainable development of energy, water and environment systems. Journal of Cleaner Production, 155(1):1-11.

Wang, Z., Xu, G., Ren, J., Li, Z., Zhang, B., Ren, X. (2017). Polygeneration system and sustainability: Multi-attribute decision-support framework for comprehensive assessment under uncertainties. 165(November 2017):1122-1137.

Wang, Y. (2016). "Public Awareness and Willingness to Pay for Tackling Smog Pollution in China: A Case Study." Journal of Cleaner Production 112(2):1627-1634.

Weissbrod, I., Bocken, N.M.P. (2017). Developing sustainable business experimentation capability - A case study. Journal of Cleaner Production. 142(4):2663-2676.

Wen, K. L., Zhao, Z. X., Zhang, H. Z., Chen, X. Y., Wen, H. Z. (2009). Grey theory (in Chinese). Taipei: Wunan.

Yang, M., Evans, S., Vladimirova, D., Rana, P. (2017). Value uncaptured perspective for sustainable business model innovation. Journal of Cleaner Production, 140(3):1794-1804.

Yin, Y.K. (1981) 'The case study crisis: some answers', Administrative Science Quarterly, 26(1):58-65.

Zhang, X., Wu, Z., Feng, Y., Xu, P. (2014). "Turning green into gold": A framework for energy performance contracting (EPC) in China's real estate industry. Journal of Cleaner Production, 109(16 December 2015):166-173. 


\begin{tabular}{|c|c|c|c|c|c|c|c|c|c|c|c|c|c|c|c|c|c|c|c|c|c|}
\hline \multirow[b]{2}{*}{ 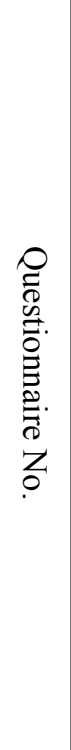 } & \multicolumn{21}{|c|}{ Part of the Questionnaires } \\
\hline & 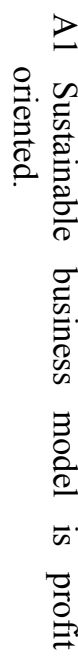 & 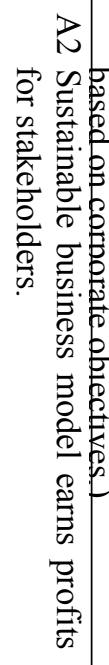 & 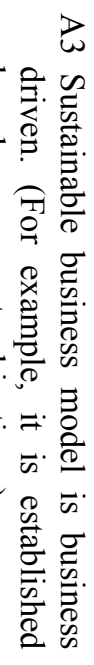 & 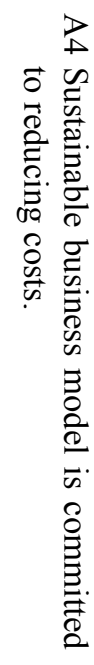 & 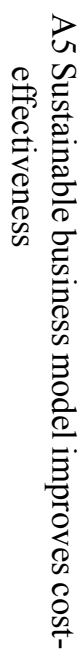 & 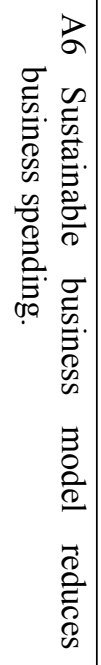 & 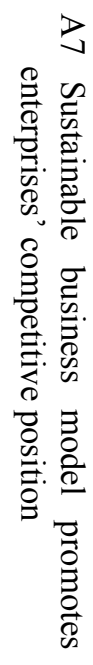 & 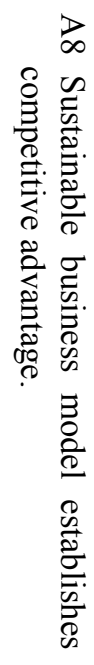 & 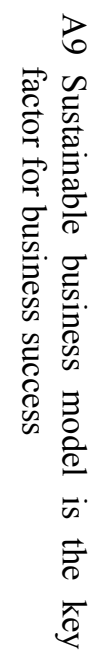 & 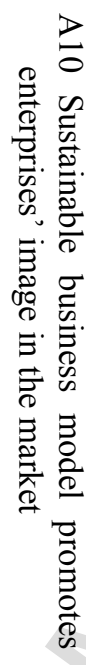 & 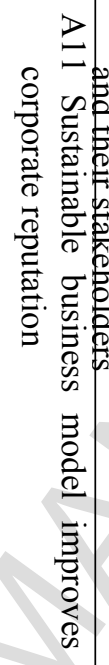 & 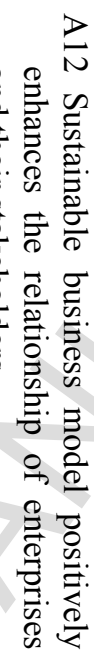 & 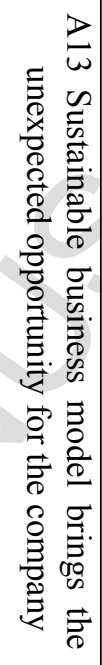 & 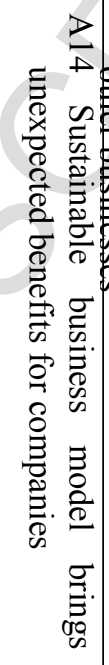 & 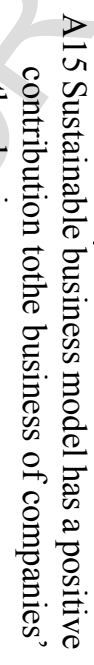 & 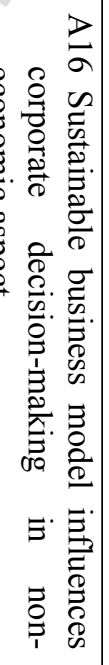 & 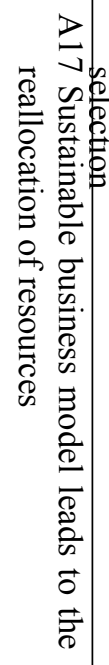 & 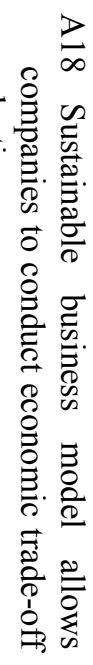 & 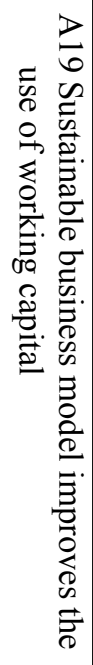 & 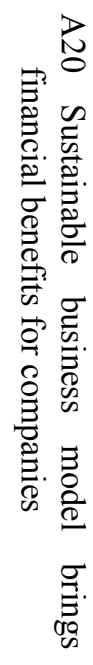 & 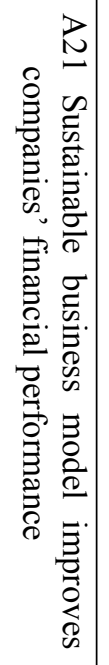 \\
\hline 1 & 2 & 5 & 4 & 3 & 3 & 3 & 4 & 4 & 4 & 3 & 4 & 5 & 4 & 4 & 4 & 4 & 4 & 4 & 4 & 4 & 5 \\
\hline 2 & 5 & 5 & 5 & 3 & 3 & 4 & 5 & & & 5 & 5 & 4 & 4 & 4 & 4 & 3 & 5 & 5 & 5 & 5 & 5 \\
\hline 3 & 3 & 3 & 4 & 4 & 4 & 4 & & & & & 3 & 3 & 3 & 3 & 3 & 3 & 4 & 4 & 3 & 3 & 3 \\
\hline 4 & 3 & 4 & 2 & 2 & 2 & 2 & & & 5 & 5 & 5 & 5 & 5 & 5 & 5 & 4 & 4 & 4 & 4 & 4 & 3 \\
\hline 5 & & 4 & 4 & 4 & 4 & 3 & & & 4 & 4 & 3 & 4 & 3 & 4 & 4 & 3 & 3 & 4 & 4 & 4 & \\
\hline 6 & & 4 & 4 & 4 & 4 & 3 & & & 4 & 4 & 4 & 3 & 4 & 4 & 4 & 3 & 3 & 3 & 4 & 4 & 4 \\
\hline 7 & & 4 & 5 & 5 & 4 & 5 & & & 3 & 3 & 4 & 4 & 5 & 4 & 3 & 3 & 3 & 3 & 4 & 5 & 4 \\
\hline & $\vdots$ & $\vdots$ & $\vdots$ & $\vdots$ & $\vdots$ & & $\vdots$ & $\vdots$ & $\vdots$ & $\vdots$ & $\vdots$ & $\vdots$ & $\vdots$ & $\vdots$ & $\vdots$ & $\vdots$ & $\vdots$ & $\vdots$ & $\vdots$ & $\vdots$ & $\vdots$ \\
\hline 232 & & 5 & 5 & 4 & 4 & & & 4 & 4 & 4 & 4 & 5 & 4 & 5 & 4 & 4 & 5 & 4 & 4 & 4 & 5 \\
\hline 233 & & 3 & 4 & & & 4 & & & 5 & 4 & & 4 & 4 & & 4 & 4 & & 3 & 3 & 3 & 3 \\
\hline
\end{tabular}




\begin{tabular}{|c|c|c|c|c|c|c|c|c|c|c|c|c|c|c|c|c|c|c|c|c|c|}
\hline \multirow[b]{2}{*}{ 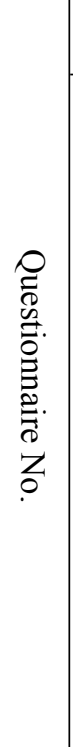 } & \multicolumn{21}{|c|}{ Part of the Questionnaires } \\
\hline & 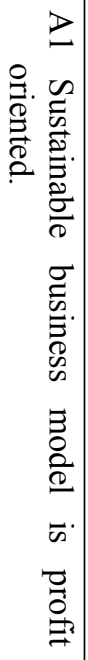 & 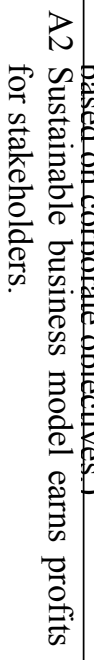 & 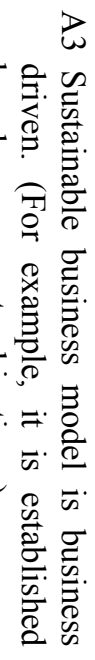 & 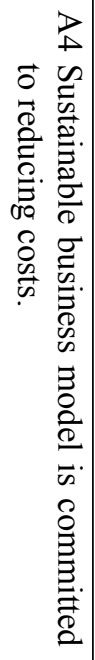 & 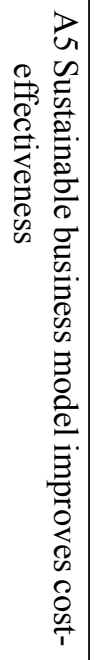 & 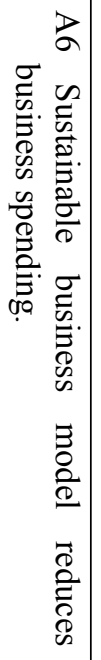 & 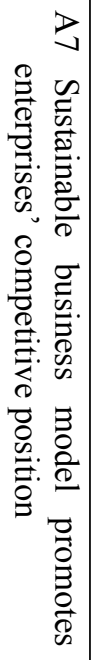 & 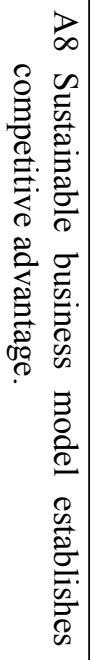 & 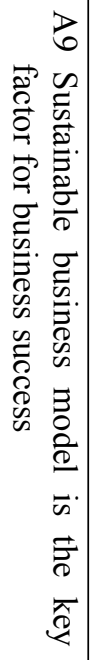 & 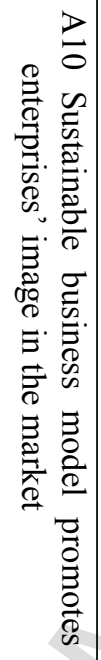 & 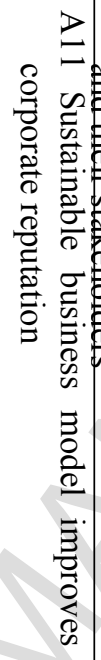 & 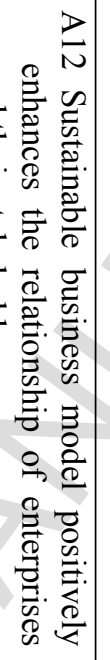 & 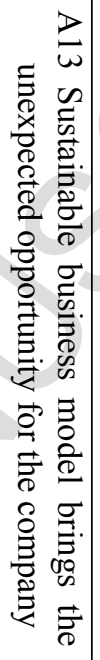 & 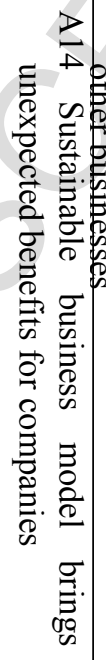 & 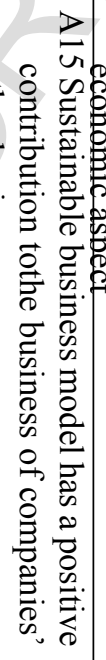 & 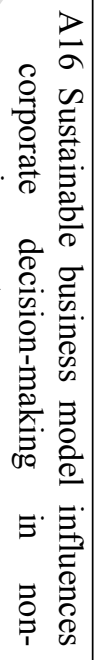 & 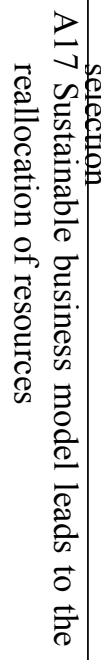 & 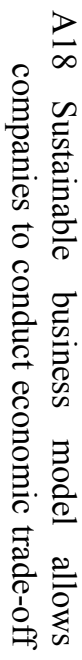 & 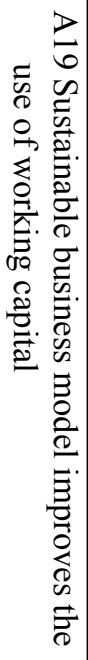 & 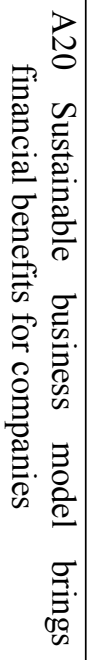 & 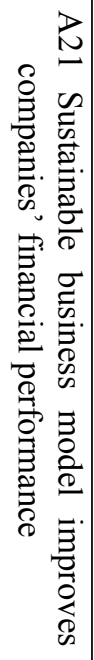 \\
\hline 1 & $1^{*}$ & 0 & 1 & 2 & 2 & 2 & 1 & 1 & 1 & 2 & $\Rightarrow$ & 0 & 1 & 1 & 1 & 1 & 1 & 1 & 1 & 1 & 0 \\
\hline 2 & 0 & 0 & 0 & 2 & 2 & 1 & 0 & 0 & 0 & 0 & 0 & 1 & 1 & 1 & 1 & 2 & 0 & 0 & 0 & 0 & 0 \\
\hline 3 & 2 & 2 & 1 & 1 & 1 & 1 & 1 & 1 & 2 & 1 & 2 & 2 & 2 & 2 & 2 & 2 & 1 & 1 & 2 & 2 & 2 \\
\hline 4 & 2 & 1 & 3 & 3 & 3 & 3 & 1 & 0 & 0 & 0 & 0 & 0 & 0 & 0 & 0 & 1 & 1 & 1 & 1 & 1 & 2 \\
\hline 5 & 0 & 1 & 1 & 1 & 1 & 2 & 1 & & 1 & 1 & 2 & 1 & 2 & 1 & 1 & 2 & 2 & 1 & 1 & 1 & 1 \\
\hline 6 & 1 & 1 & 1 & 1 & 1 & 2 & & 2 & 1 & 1 & 1 & 2 & 1 & 1 & 1 & 2 & 2 & 2 & 1 & 1 & 1 \\
\hline 7 & 1 & 1 & 0 & 0 & 1 & 0 & & & 2 & 2 & 1 & 1 & 0 & 1 & 2 & 2 & 2 & 2 & 1 & 0 & 1 \\
\hline : & $\vdots$ & $\vdots$ & $\vdots$ & $\vdots$ & $\vdots$ & : & $\vdots$ & $\vdots$ & $\vdots$ & $\vdots$ & $\vdots$ & $\vdots$ & $\vdots$ & $\vdots$ & $\vdots$ & $\vdots$ & $\vdots$ & $\vdots$ & $\vdots$ & $\vdots$ & $\vdots$ \\
\hline 232 & 0 & 0 & 0 & 1 & 1 & 1 & 1 & 1 & 1 & 1 & 1 & 0 & 1 & 0 & 1 & 1 & 0 & 1 & 1 & 1 & 0 \\
\hline 233 & 3 & 2 & 1 & 1 & 1 & & 0 & 0 & 0 & 1 & 2 & 1 & 1 & 1 & 1 & 1 & 1 & 2 & 2 & 2 & 2 \\
\hline
\end{tabular}

Note: *represents $\left|x_{0}(k)-x_{i}(k)\right|=5-4=1$ 


\begin{tabular}{|c|c|c|c|c|c|c|c|c|c|c|c|c|c|c|c|c|c|c|c|c|c|}
\hline \multirow[b]{2}{*}{ 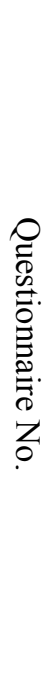 } & \multicolumn{21}{|c|}{ Part of the Questionnaires } \\
\hline & 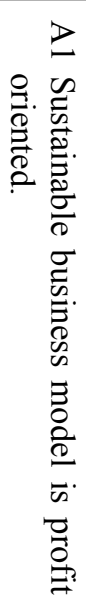 & 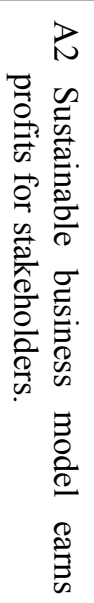 & 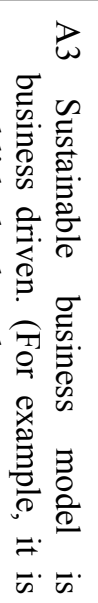 & 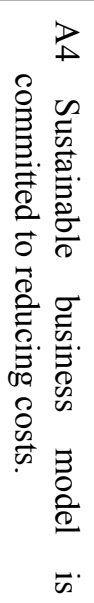 & 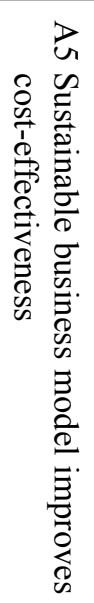 & 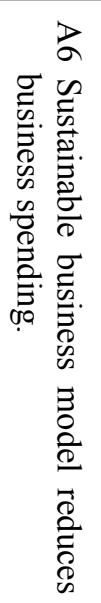 & 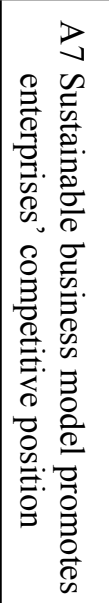 & 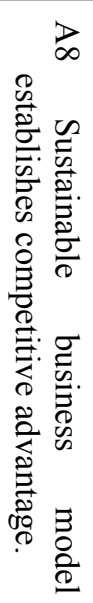 & 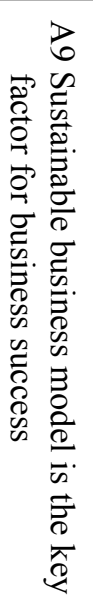 & 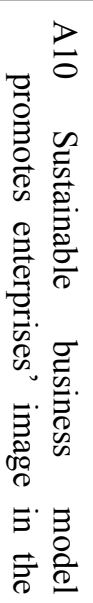 & 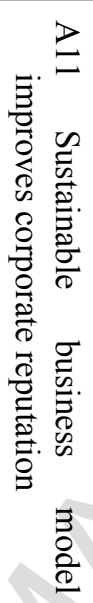 & 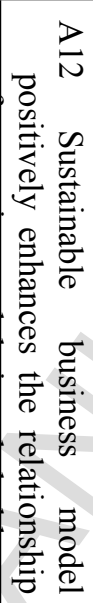 & 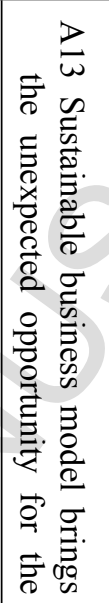 & 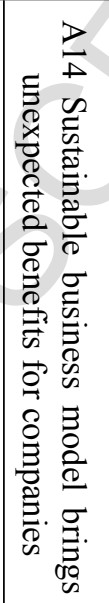 & 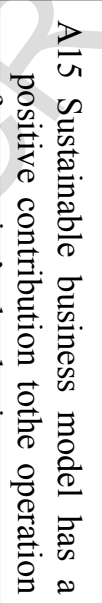 & 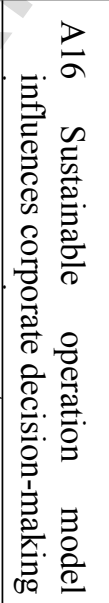 & 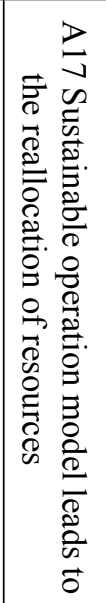 & 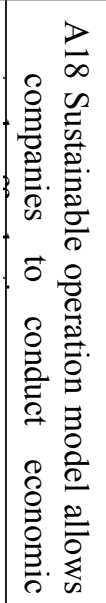 & 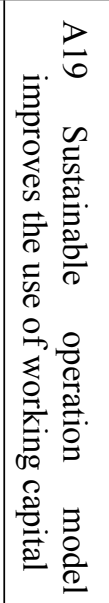 & 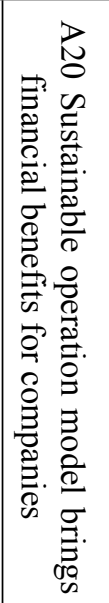 & 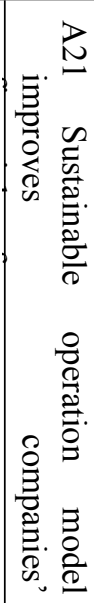 \\
\hline 1 & $\begin{array}{r}0.66 \\
6 \\
7 \\
*\end{array}$ & $\begin{array}{r}1.00 \\
0 \\
0\end{array}$ & $\begin{array}{r}0.66 \\
6 \\
7\end{array}$ & $\begin{array}{r}0.50 \\
0\end{array}$ & $\begin{array}{r}0.50 \\
0 \\
0\end{array}$ & $\begin{array}{r}0.50 \\
0 \\
0\end{array}$ & $\begin{array}{r}0.66 \\
6 \\
7\end{array}$ & $\begin{array}{r}0.66 \\
6 \\
7\end{array}$ & $\begin{array}{r}0.66 \\
6 \\
7\end{array}$ & $\begin{array}{r}0.50 \\
0 \\
0\end{array}$ & $\begin{array}{r}0.66 \\
6 \\
7\end{array}$ & $\begin{array}{r}1.00 \\
0 \\
0\end{array}$ & $\begin{array}{r}0.66 \\
6 \\
7\end{array}$ & $\begin{array}{r}0.66 \\
6 \\
7\end{array}$ & $\begin{array}{r}0.71 \\
4 \\
3\end{array}$ & $\begin{array}{r}0.66 \\
6 \\
7\end{array}$ & $\begin{array}{r}0.66 \\
6 \\
7\end{array}$ & $\begin{array}{r}0.60 \\
0\end{array}$ & $\begin{array}{r}0.71 \\
4 \\
3\end{array}$ & $\begin{array}{r}0.66 \\
6 \\
7\end{array}$ & $\begin{array}{r}1.00 \\
0 \\
0\end{array}$ \\
\hline 2 & $\begin{array}{r}1.00 \\
0 \\
0\end{array}$ & $\begin{array}{r}1.00 \\
0 \\
0\end{array}$ & $\begin{array}{r}1.00 \\
0 \\
0\end{array}$ & $\begin{array}{r}0.50 \\
0 \\
0\end{array}$ & $\begin{array}{r}0.50 \\
0 \\
0\end{array}$ & $\begin{array}{r}0.66 \\
6 \\
7\end{array}$ & $\begin{array}{r}1.00 \\
0 \\
0\end{array}$ & $\begin{array}{r}1.00 \\
0 \\
0\end{array}$ & & $\begin{array}{r}1.00 \\
0 \\
0\end{array}$ & $\begin{array}{r}1.00 \\
0 \\
0\end{array}$ & $\begin{array}{r}0.60 \\
0 \\
0\end{array}$ & $\begin{array}{r}0.66 \\
6 \\
7\end{array}$ & $\begin{array}{r}0.66 \\
6 \\
7\end{array}$ & $\begin{array}{r}0.71 \\
4 \\
3\end{array}$ & $\begin{array}{r}0.50 \\
0 \\
0\end{array}$ & $\begin{array}{r}1.00 \\
0 \\
0\end{array}$ & $\begin{array}{r}1.00 \\
0 \\
0\end{array}$ & $\begin{array}{r}1.00 \\
0 \\
0\end{array}$ & $\begin{array}{r}1.00 \\
0 \\
0\end{array}$ & $\begin{array}{r}1.00 \\
0 \\
0\end{array}$ \\
\hline 3 & $\begin{array}{r}0.50 \\
0 \\
0\end{array}$ & $\begin{array}{r}0.50 \\
0 \\
0\end{array}$ & $\begin{array}{r}0.66 \\
6 \\
7\end{array}$ & $\begin{array}{r}0.66 \\
6 \\
7\end{array}$ & $\begin{array}{r}0.66 \\
6 \\
7\end{array}$ & $\begin{array}{r}0.66 \\
6 \\
7\end{array}$ & $\begin{array}{r}0.66 \\
6 \\
7\end{array}$ & & $\begin{array}{r}0.50 \\
0 \\
0\end{array}$ & $\begin{array}{r}0.66 \\
6 \\
7\end{array}$ & $\begin{array}{r}0.50 \\
0 \\
0\end{array}$ & $\begin{array}{r}0.42 \\
8 \\
6\end{array}$ & $\begin{array}{r}0.50 \\
0 \\
0\end{array}$ & $\begin{array}{r}0.50 \\
0 \\
0\end{array}$ & $\begin{array}{r}0.55 \\
5 \\
6\end{array}$ & $\begin{array}{r}0.50 \\
0 \\
0\end{array}$ & $\begin{array}{r}0.66 \\
6 \\
7\end{array}$ & $\begin{array}{r}0.60 \\
0 \\
0\end{array}$ & $\begin{array}{r}0.55 \\
5 \\
6\end{array}$ & $\begin{array}{r}0.50 \\
0 \\
0\end{array}$ & $\begin{array}{r}0.50 \\
0 \\
0\end{array}$ \\
\hline 4 & $\begin{array}{r}0.50 \\
0 \\
0\end{array}$ & $\begin{array}{r}0.66 \\
6 \\
7\end{array}$ & $\begin{array}{r}0.40 \\
0 \\
0\end{array}$ & $\begin{array}{r}0.40 \\
0 \\
0\end{array}$ & $\begin{array}{r}0.40 \\
0 \\
0\end{array}$ & $\begin{array}{r}0.40 \\
0 \\
0\end{array}$ & $\begin{array}{r}0.66 \\
6 \\
7\end{array}$ & & $\begin{array}{r}1.00 \\
0 \\
0\end{array}$ & $\begin{array}{r}1.00 \\
0 \\
0\end{array}$ & $\begin{array}{r}1.00 \\
0 \\
0\end{array}$ & $\begin{array}{r}1.00 \\
0 \\
0\end{array}$ & $\begin{array}{r}1.00 \\
0 \\
0\end{array}$ & $\begin{array}{r}1.00 \\
0 \\
0\end{array}$ & $\begin{array}{r}1.00 \\
0 \\
0\end{array}$ & $\begin{array}{r}0.66 \\
6 \\
7\end{array}$ & $\begin{array}{r}0.66 \\
6 \\
7\end{array}$ & $\begin{array}{r}0.60 \\
0 \\
0\end{array}$ & $\begin{array}{r}0.71 \\
4 \\
3\end{array}$ & $\begin{array}{r}0.66 \\
6 \\
7\end{array}$ & $\begin{array}{r}0.50 \\
0 \\
0\end{array}$ \\
\hline 5 & $\begin{array}{r}1.00 \\
0 \\
0\end{array}$ & $\begin{array}{r}0.66 \\
6 \\
7\end{array}$ & $\begin{array}{r}0.66 \\
6 \\
7\end{array}$ & $\begin{array}{r}0.66 \\
6 \\
7\end{array}$ & $\begin{array}{r}0.66 \\
6 \\
7\end{array}$ & $\begin{array}{r}0.50 \\
0 \\
0\end{array}$ & $\begin{array}{r}0.66 \\
6 \\
7\end{array}$ & $\begin{array}{r}0.66 \\
6 \\
7\end{array}$ & $\begin{array}{r}0.66 \\
6 \\
7\end{array}$ & $\begin{array}{r}0.66 \\
6 \\
7\end{array}$ & $\begin{array}{r}0.50 \\
0 \\
0\end{array}$ & $\begin{array}{r}0.60 \\
0 \\
0\end{array}$ & $\begin{array}{r}0.50 \\
0 \\
0\end{array}$ & $\begin{array}{r}0.66 \\
6 \\
7\end{array}$ & $\begin{array}{r}0.71 \\
4 \\
3\end{array}$ & $\begin{array}{r}0.50 \\
0 \\
0\end{array}$ & $\begin{array}{r}0.50 \\
0 \\
0\end{array}$ & $\begin{array}{r}0.60 \\
0 \\
0\end{array}$ & $\begin{array}{r}0.71 \\
4 \\
3\end{array}$ & $\begin{array}{r}0.66 \\
6 \\
7\end{array}$ & $\begin{array}{r}0.66 \\
6 \\
7\end{array}$ \\
\hline 6 & $\begin{array}{r}0.66 \\
6 \\
7\end{array}$ & $\begin{array}{r}0.66 \\
6 \\
7\end{array}$ & $\begin{array}{r}0.66 \\
6 \\
7\end{array}$ & $\begin{array}{r}0.66 \\
6 \\
7\end{array}$ & $\begin{array}{r}0.66 \\
6 \\
7\end{array}$ & $\begin{array}{r}0.50 \\
0 \\
0\end{array}$ & $\begin{array}{r}0.50 \\
0 \\
0\end{array}$ & $\begin{array}{r}0.50 \\
0 \\
0\end{array}$ & $\begin{array}{r}0.66 \\
6 \\
7\end{array}$ & $\begin{array}{r}0.66 \\
6 \\
7\end{array}$ & $\begin{array}{r}0.66 \\
6 \\
7\end{array}$ & $\begin{array}{r}0.42 \\
8 \\
6\end{array}$ & $\begin{array}{r}0.66 \\
6 \\
7\end{array}$ & $\begin{array}{r}0.66 \\
6 \\
7\end{array}$ & $\begin{array}{r}0.71 \\
4 \\
3\end{array}$ & $\begin{array}{r}0.50 \\
0 \\
0\end{array}$ & $\begin{array}{r}0.50 \\
0 \\
0\end{array}$ & $\begin{array}{r}0.42 \\
8 \\
6\end{array}$ & $\begin{array}{r}0.71 \\
4 \\
3\end{array}$ & $\begin{array}{r}0.66 \\
6 \\
7\end{array}$ & $\begin{array}{r}0.66 \\
6 \\
7\end{array}$ \\
\hline
\end{tabular}




\begin{tabular}{|c|c|c|c|c|c|c|c|c|c|c|c|c|c|c|c|c|c|c|c|c|c|}
\hline 7 & $\begin{array}{r}0.66 \\
6 \\
7\end{array}$ & $\begin{array}{r}0.66 \\
6 \\
7\end{array}$ & $\begin{array}{r}1.00 \\
0 \\
0\end{array}$ & $\begin{array}{r}1.00 \\
0 \\
0\end{array}$ & $\begin{array}{r}0.66 \\
6 \\
7\end{array}$ & $\begin{array}{r}1.00 \\
0 \\
0\end{array}$ & $\begin{array}{r}0.50 \\
0 \\
0\end{array}$ & $\begin{array}{r}0.50 \\
0 \\
0\end{array}$ & $\begin{array}{r}0.50 \\
0 \\
0\end{array}$ & $\begin{array}{r}0.50 \\
0 \\
0\end{array}$ & $\begin{array}{r}0.66 \\
6 \\
7\end{array}$ & $\begin{array}{r}0.60 \\
0 \\
0\end{array}$ & $\begin{array}{r}1.00 \\
0 \\
0\end{array}$ & $\begin{array}{r}0.66 \\
6 \\
7\end{array}$ & $\begin{array}{r}0.55 \\
5 \\
6\end{array}$ & $\begin{array}{r}0.50 \\
0 \\
0\end{array}$ & $\begin{array}{r}0.50 \\
0 \\
0\end{array}$ & $\begin{array}{r}0.42 \\
8 \\
6\end{array}$ & $\begin{array}{r}0.71 \\
4 \\
3\end{array}$ & $\begin{array}{r}1.00 \\
0 \\
0\end{array}$ & $\begin{array}{r}0.66 \\
6 \\
7\end{array}$ \\
\hline : & $\vdots$ & $\vdots$ & $\vdots$ & $\vdots$ & $\vdots$ & $\vdots$ & $\vdots$ & $\vdots$ & $\vdots$ & $\vdots$ & $\vdots$ & $\vdots$ & $\vdots$ & & $\vdots$ & $\nabla$ & $\vdots$ & $\vdots$ & $\vdots$ & $\vdots$ & $\vdots$ \\
\hline 232 & $\begin{array}{r}1.00 \\
0 \\
0\end{array}$ & $\begin{array}{r}1.00 \\
0 \\
0\end{array}$ & $\begin{array}{r}1.00 \\
0 \\
0\end{array}$ & $\begin{array}{r}0.66 \\
6 \\
7\end{array}$ & $\begin{array}{r}0.66 \\
6 \\
7\end{array}$ & $\begin{array}{r}0.66 \\
6 \\
7\end{array}$ & $\begin{array}{r}0.66 \\
6 \\
7\end{array}$ & $\begin{array}{r}0.66 \\
6 \\
7\end{array}$ & $\begin{array}{r}0.66 \\
6 \\
7\end{array}$ & $\begin{array}{r}0.66 \\
6 \\
7\end{array}$ & $\begin{array}{r}0.66 \\
6 \\
7\end{array}$ & $\begin{array}{r}1.00 \\
0 \\
0\end{array}$ & $\begin{array}{r}0.66 \\
6 \\
7\end{array}$ & $\begin{array}{r}1.00 \\
0 \\
0\end{array}$ & $\begin{array}{r}0.71 \\
4 \\
3\end{array}$ & $\begin{array}{r}0.66 \\
6 \\
7\end{array}$ & $\begin{array}{r}1.00 \\
0 \\
0\end{array}$ & $\begin{array}{r}0.60 \\
0 \\
0\end{array}$ & $\begin{array}{r}0.71 \\
4 \\
3\end{array}$ & $\begin{array}{r}0.66 \\
6 \\
7\end{array}$ & $\begin{array}{r}1.00 \\
0 \\
0\end{array}$ \\
\hline 233 & $\begin{array}{r}0.40 \\
0 \\
0\end{array}$ & $\begin{array}{r}0.50 \\
0 \\
0\end{array}$ & $\begin{array}{r}0.66 \\
6 \\
7\end{array}$ & $\begin{array}{r}0.66 \\
6 \\
7\end{array}$ & $\begin{array}{r}0.66 \\
6 \\
7\end{array}$ & $\begin{array}{r}0.66 \\
6 \\
7\end{array}$ & $\begin{array}{r}1.00 \\
0 \\
0\end{array}$ & $\begin{array}{r}1.00 \\
0 \\
0\end{array}$ & $\begin{array}{r}1.00 \\
0 \\
0\end{array}$ & $\begin{array}{r}0.66 \\
6 \\
7\end{array}$ & $\begin{array}{r}0.50 \\
0 \\
0\end{array}$ & $\begin{array}{r}0.60 \\
0 \\
0\end{array}$ & $\begin{array}{r}0.66 \\
6 \\
7\end{array}$ & $\begin{array}{r}0.66 \\
6 \\
7\end{array}$ & $\begin{array}{r}0.71 \\
4 \\
3\end{array}$ & $\begin{array}{r}0.66 \\
6 \\
7\end{array}$ & $\begin{array}{r}0.66 \\
6 \\
7\end{array}$ & $\begin{array}{r}0.42 \\
8 \\
6\end{array}$ & $\begin{array}{r}0.55 \\
5 \\
6\end{array}$ & $\begin{array}{r}0.50 \\
0 \\
0\end{array}$ & $\begin{array}{r}0.50 \\
0 \\
0\end{array}$ \\
\hline
\end{tabular}

Note: *represents $r\left(x_{0}(k), \mathrm{x}(k)\right)=(\Delta \min +\zeta \Delta \max ) /\left(\Delta_{\mathrm{oi}}(k)+\zeta \Delta \max \right)=(0+0.5 \times 4) /(1+0.5 \times 4)=0.6667$ 
Appendix 4. Grey relational value and grey relational sequence in the economic dimension

\begin{tabular}{|c|c|c|c|}
\hline & ACCEPTED MANUSCRIP & & \\
\hline No. & Title & $\begin{array}{l}\text { Grey } \\
\text { relational } \\
\text { value }\end{array}$ & $\begin{array}{c}\text { Grey relational } \\
\text { sequence }\end{array}$ \\
\hline A8 & $\begin{array}{c}\text { Sustainable operation model establishes competitive } \\
\text { advantage. }\end{array}$ & 0.7568 & 1 \\
\hline A7 & $\begin{array}{c}\text { Sustainable operation model promotes enterprises' } \\
\text { competitive position. }\end{array}$ & 0.7411 & 2 \\
\hline A15 & $\begin{array}{l}\text { Sustainable operation model has a positive contribution to } \\
\text { the operation of companies' other businesses. }\end{array}$ & 0.7353 & 3 \\
\hline A10 & $\begin{array}{l}\text { Sustainable operation model promotes enterprises' image } \\
\text { in the market. }\end{array}$ & 0.7336 & 4 \\
\hline A9 & $\begin{array}{c}\text { Sustainable operation model is the key factor for business } \\
\text { success. }\end{array}$ & 0.7251 & 5 \\
\hline A11 & $\begin{array}{c}\text { Sustainable operation model improves corporate } \\
\text { reputation. }\end{array}$ & 0.6968 & 6 \\
\hline A19 & $\begin{array}{l}\text { Sustainable operation model improves the use of working } \\
\text { capital. }\end{array}$ & 0.6911 & 7 \\
\hline A16 & $\begin{array}{l}\text { Sustainable operation model influences corporate decision- } \\
\text { making in non-economic aspect. }\end{array}$ & 0.6784 & 8 \\
\hline A5 & Sustainable operation model improves cost-effectiveness. & 0.6684 & 9 \\
\hline A14 & $\begin{array}{l}\text { Sustainable operation model brings unexpected benefits } \\
\text { for companies. }\end{array}$ & 0.6534 & 10 \\
\hline A13 & $\begin{array}{l}\text { Sustainable business model brings the unexpected } \\
\text { opportunity for the company. }\end{array}$ & 0.6502 & 11 \\
\hline A17 & $\begin{array}{l}\text { Sustainable operation model leads to the } \\
\text { reallocation of resources. }\end{array}$ & 0.6494 & 12 \\
\hline A12 & $\begin{array}{l}\text { Sustainable operation model positively enhances the } \\
\text { relationship of enterprises and their stakeholders. }\end{array}$ & 0.6397 & 13 \\
\hline A3 & $\begin{array}{c}\text { Sustainable operation model is business driven. (For } \\
\text { example, it is established based on corporate } \\
\text { objectives.) }\end{array}$ & 0.6388 & 14 \\
\hline
\end{tabular}




\begin{tabular}{|c|c|c|c|}
\hline A20 & $\begin{array}{l}\text { Sustainable operation model brings financial benefits for } \\
\text { companies. }\end{array}$ & 0.6328 & 15 \\
\hline A21 & $\begin{array}{l}\text { Sustainable operation model improves companies' } \\
\text { financial performance. }\end{array}$ & 0.6209 & 16 \\
\hline A1 & Sustainable operation model is profit oriented. & 0.6104 & 17 \\
\hline A2 & Sustainable operation model earns profits for stakeholders. & 0.6102 & 18 \\
\hline A6 & Sustainable operation model reduces business spending. & 0.5782 & 19 \\
\hline A18 & $\begin{array}{l}\text { Sustainable operation model allows companies to conduct } \\
\text { economic trade-off selection. }\end{array}$ & 0.5758 & 20 \\
\hline A4 & $\begin{array}{l}\text { Sustainable operation model is committed to reducing } \\
\text { costs. }\end{array}$ & 0.5664 & 21 \\
\hline
\end{tabular}


Appendix 5. Grey relational value and grey relational sequence in the social dimension

\begin{tabular}{|c|c|c|c|}
\hline No. & Title & $\begin{array}{l}\text { Grey } \\
\text { relational } \\
\text { value }\end{array}$ & $\begin{array}{l}\text { Grey } \\
\text { relational } \\
\text { sequence }\end{array}$ \\
\hline B8 & Sustainable operation model can show corporate value. & 0.7693 & 1 \\
\hline B13 & $\begin{array}{l}\text { The operation of sustainable operation model requires } \\
\text { enterprises to put a lot of efforts. }\end{array}$ & 0.7669 & 2 \\
\hline B11 & $\begin{array}{l}\text { The operation of sustainable operation model has a positive } \\
\text { impact on companies' reputation. }\end{array}$ & 0.7622 & 3 \\
\hline B16 & $\begin{array}{l}\text { Sustainable operation model is established based on business } \\
\text { continuity. }\end{array}$ & 0.7595 & 4 \\
\hline B18 & $\begin{array}{l}\text { Sustainable operation model is performed with the } \\
\text { agreement of all colleagues of the companies. }\end{array}$ & 0.7574 & 5 \\
\hline B10 & $\begin{array}{l}\text { The operation results of sustainable operation model } \\
\text { positively enhance companies' reputation. }\end{array}$ & 0.7496 & 6 \\
\hline B17 & The operation of sustainable operation model requires the & 0.7487 & 7 \\
\hline B4 & $\begin{array}{l}\text { Sustainable operation model is meaningless without the } \\
\text { support of company employees. }\end{array}$ & 0.7455 & 8 \\
\hline B9 & $\begin{array}{l}\text { Sustainable operation model is established based on business } \\
\text { principles. }\end{array}$ & 0.7359 & 9 \\
\hline B7 & Sustainable operation model reflects corporate norms. & 0.7279 & 10 \\
\hline B6 & $\begin{array}{l}\text { Sustainable operation model has no influence without the } \\
\text { support of companies' leaderships. }\end{array}$ & 0.7230 & 11 \\
\hline B5 & $\begin{array}{l}\text { Sustainable operation model has no influence without the } \\
\text { support of companies' leaderships. }\end{array}$ & 0.7187 & 12 \\
\hline B21 & Sustainable operation model can be widely reported. & 0.7179 & 13 \\
\hline
\end{tabular}




\begin{tabular}{|c|c|c|c|}
\hline B2 & $\begin{array}{l}\text { Sustainable operation model shall have common ambitions } \\
\text { with the companies' business networks. }\end{array}$ & 0.7115 & 14 \\
\hline B12 & $\begin{array}{c}\text { Sustainable operation model gains good evaluation from } \\
\text { stakeholders. }\end{array}$ & 0.7034 & 15 \\
\hline B20 & $\begin{array}{l}\text { Sustainable operation model is open and transparent } \\
\text { publicly. }\end{array}$ & 0.6987 & 16 \\
\hline B19 & $\begin{array}{l}\text { Sustainable operation model is available to public } \\
\text { supervision. }\end{array}$ & 0.6967 & 17 \\
\hline B1 & $\begin{array}{l}\text { Sustainable operation model shall have common ambitions } \\
\text { with the companies' business networks. }\end{array}$ & 0.6825 & 18 \\
\hline B3 & $\begin{array}{l}\text { Sustainable operation model shall be used by all business } \\
\text { partners of the companies. }\end{array}$ & 0.6728 & 19 \\
\hline B15 & $\begin{array}{l}\text { The operation of sustainable operation model is established } \\
\text { based on dedication. }\end{array}$ & 0.6711 & 20 \\
\hline B14 & $\begin{array}{l}\text { The operation of sustainable operation model requires } \\
\text { enterprises to invest a lot. }\end{array}$ & 0.6668 & 21 \\
\hline
\end{tabular}


Appendix 6. Grey relational value and grey relational sequence in the environmental dimension

\begin{tabular}{|c|c|c|c|}
\hline No. & Title & $\begin{array}{l}\text { Grey } \\
\text { relation } \\
\text { al value }\end{array}$ & $\begin{array}{l}\text { Grey } \\
\text { relational } \\
\text { sequence }\end{array}$ \\
\hline $\mathrm{C} 17$ & $\begin{array}{l}\text { The quality of sustainable operation model is strictly } \\
\text { controlled through continuous improvement. }\end{array}$ & 0.7714 & 1 \\
\hline C9 & Sustainable operation model is made up of many measures. & 0.7436 & 2 \\
\hline $\mathrm{C} 16$ & $\begin{array}{c}\text { Sustainable operation model is considered to be suitable in } \\
\text { natural environment protection. }\end{array}$ & 0.7369 & 3 \\
\hline $\mathrm{C} 7$ & $\begin{array}{l}\text { Sustainable operation model involves comprehensive } \\
\text { strategic efforts from companies. }\end{array}$ & 0.7339 & 4 \\
\hline $\mathrm{C} 2$ & $\begin{array}{c}\text { Sustainable operation model takes the influences of the } \\
\text { partners' enterprises on ecological environment into } \\
\text { consideration. }\end{array}$ & 0.7251 & 5 \\
\hline $\mathrm{C} 18$ & Sustainable operation model is a continuous process. & 0.7168 & 6 \\
\hline $\mathrm{C} 15$ & $\begin{array}{l}\text { Sustainable operation model helps to hold activities about } \\
\text { the influences of products on ecological environment. }\end{array}$ & 0.7080 & 7 \\
\hline $\mathrm{C} 13$ & $\begin{array}{l}\text { Sustainable business model makes the company's products } \\
\text { more environmentally friendly }\end{array}$ & 0.7078 & 8 \\
\hline $\mathrm{C} 14$ & Sustainable business model should be able to generate profit. & 0.7065 & 9 \\
\hline $\mathrm{C} 10$ & $\begin{array}{l}\text { Sustainable operation model marks the influences of each } \\
\text { product on natural environment. }\end{array}$ & 0.7026 & 10 \\
\hline $\mathrm{C} 11$ & Sustainable operation model focuses on each product's & 0.7013 & 11 \\
\hline $\mathrm{C} 8$ & $\begin{array}{c}\text { Sustainable operation model is beyond the companies } \\
\text { themselves. }\end{array}$ & 0.6912 & 12 \\
\hline $\mathrm{C} 3$ & $\begin{array}{c}\text { Sustainable operation model can reduce enterprises' } \\
\text { influences on ecological environment. }\end{array}$ & 0.6856 & 13 \\
\hline
\end{tabular}




\begin{tabular}{|c|c|c|c|}
\hline C1 & $\begin{array}{c}\text { Sustainable operation model can reduce business partners' } \\
\text { enterprises' influences on ecological environment. }\end{array}$ & 0.6847 & 14 \\
\hline C6 & $\begin{array}{c}\text { Sustainable operation model strives to reduce the } \\
\text { greenhouse gas emissions to a minimum. }\end{array}$ & 0.6838 & 15 \\
\hline C5 & $\begin{array}{c}\text { Sustainable operation model takes the influences of global } \\
\text { warming on the companies' businesses into } \\
\text { consideration. }\end{array}$ & 0.6815 & 16 \\
\hline C4 & $\begin{array}{r}\text { Sustainable operation model takes the issue of climate } \\
\text { change into consideration. }\end{array}$ & 0.6772 & 18 \\
\hline C12 & $\begin{array}{r}\text { Sustainable operation model is apparent to stakeholders } \\
\text { (such as shareholders) }\end{array}$ & 0.6527 & 17 \\
\hline
\end{tabular}


Appendix 7. Groups from the economic dimension

(1) Group One: 「A8 Sustainable business model establishes competitive advantage.」(the grey relational value is 0.7568 )

(2) Group Two 「A7 Sustainable business model promotes enterprises' competitive position」(the grey relational value is 0.7411$)$, 「A15 Sustainable business model has a positive contribution tothe operation of companies' other businesses 」(the grey relational value is 0.7353 ), 「A10 Sustainable business model promotes enterprises' image in the market.」(the grey relational value is 0.7336 ), 「A9 Sustainable business model is the key factor for business success $\rfloor$ (the grey relational value is 0.7251 ).

(3) Group Three: 「A11Sustainable business model improves corporate reputation」(the grey relational value is 0.6968 ) , 「A19 Sustainable business model improves the use of working capital」(the grey relational value is 0.6911 )

(4) Group Four: 「A16Sustainable business model influences corporate decision-making in non-economic aspect」(the grey relational value is 0.6784 ), 「A5 Sustainable business model improves costeffectiveness. $\rfloor$ the grey relational value is 0.6684 )

(5) Group Five: 「A14Sustainable business model brings unexpected benefits for companies」(the grey relational value is 0.6534$)$, 「A13Sustainable business model bring the unexpected opportunity for the company」(the grey relational value is 0.6502 ), 「A17Sustainable business model leads to the reallocation of resources $\rfloor$ (the grey relational value is 0.6494 )

(6) Group Six: 「A12Sustainable business model positively enhances the relationship of enterprises and their stakeholders.」(the grey relational value is 0.6397), 「A3 Sustainable business model is business driven.(For example, it is established based on corporate objectives.)」(the grey relational value is 0.6388 ) , 「A20Sustainable business model brings financial benefits for companies 」(the grey relational value is 0.6328 )

(7) Group Seven:「A21Sustainable business model improves companies' financial performance $\rfloor$ (the grey relational value is 0.6209 ) , 「A1 Sustainable business model is profit oriented.」（the grey relational value is 0.6104 ) , 「A2 Sustainable business model earns profits for stakeholders.」(the grey relational value is 0.6102 )

(8) Group Eight: 「A6Sustainable business model reduces business spending.」(the grey relational value is 0.5782 ) , 「A18Sustainable business model allows companies to conduct economic trade-off selection. 」 ( the grey relational value is 0.5758 ), 「A4 Sustainable business model is committed to reducing costs. 」 (the grey relational value is 0.5664 ) 
Appendix 8. Groups from the social dimension

(1) Group One: 「B8 Sustainable business model can show corporate value $\rfloor$ (the grey relational value is $0.7693),\lceil\mathrm{B} 13$ The operation of sustainable business model requires enterprises to put a lot of efforts 」 (the grey relational value is 0.7669 )

(2) Group Two: 「B11The operation of sustainable business model has a positive impact on companies' reputation」 (the grey relational value is 0.7622 ), 「B16 Sustainable business model is established based on business continuity」（the grey relational value is 0.7595 ), 「B18Sustainable business model is performed with the agreement of all colleagues of the companies. (the grey relational value is 0.7574 )

(3) Group Three: 「B10The operation results of sustainable business model positively enhances companies' reputation 」 (the grey relational value is 0.7496 ), 「B17The operation of sustainable business model requires the consistency of companies' decisions $\rfloor$ (the grey relational value is 0.7487 ), B4B4sustainable business model is meaningless without the support of company employees.」（the grey relational value is 0.7455 )

(4) Group Four: 「B9Sustainable business model is established based on business principles」 (the grey relational value is 0.7359 ), 「B7Sustainable business model reflects corporate norms」 (the grey relational value is 0.7279 ), $\lceil\mathrm{B} 6$ Sustainable business model has no influence without the support of companies' leaderships.」 (the grey relational value is 0.7230 )

(5) Group Five: 「B5Sustainable business model has no influence without the support of companies' leaderships.」 (the grey relational value is 0.7187), 「B21Sustainable business model can be widely reported 」 (the grey relational value is 0.7179 ), 「B2Sustainable business model shall have common ambitions with the companies' business networks 」（the grey relational value is 0.7115 )

(6) Group Six: 「B12Sustainable business model gains good evaluation from stakeholders. 」 (the grey relational value is 0.7034$)$, 「B20Sustainable business model is open and transparent publicly」 (the grey relational value is 0.6987$),\lceil\mathrm{B} 19$ Sustainable business model is available to public supervision 」

(the grey relational value is 0.6967 )

(7) Group Seven: 「B1Sustainable business model shall have common ambitions with the companies' business networks .」 (the grey relational value is 0.6825 ), , B3Sustainable business model shall be used by all business partners of the companies」 (the grey relational value is 0.6728 ), 「B15 The operation of sustainable business model is established based on dedication 」 (the grey relational value is $0.6711)$, 「B14The operation of sustainable business model requires enterprises to invest a lot $\rfloor$ (the grey relational value is 0.6668 ) 
Appendix 9. Groups from the environmental dimension

(1) Group One: 「C17The quality of sustainable business model is strictly controlled through continuous improvement $\rfloor \quad$ (the grey relational value is 0.7714 )

(2) Group Two: 「C9Sustainable business model is made up of many measures.」 (the grey relational value is 0.7436$)$, $\lceil\mathrm{C} 16$ Sustainable business model is considered to be suitable in natural environment protection 」 (the grey relational value is 0.7369$),\lceil\mathrm{C} 7$ sustainable business model involves the efforts of the company's comprehensive strategy (comprehensive strategic effort from company)」 (the grey relational value is 0.7339 )

(3) Group Three: 「C2Sustainable business model takes the influences of the partners' enterprises on ecological environment into consideration」 (the grey relational value is 0.7251$),\lceil\mathrm{C} 18$ sustainable business model is a continuous process. $\rfloor \quad$ ( the grey relational value is 0.7168 )

(4) Group Four: 「C15Sustainable business model helps to hold activities about the influences of products on ecological environment $\rfloor$ (the grey relational value is 0.7080$),\lceil$ C13Sustainable business model makes the company's products more environmentally friendly $\rfloor$ (the grey relational value is 0.7078 ), $\lceil\mathrm{C} 14$ Sustainable business model should be able to generate profit $\rfloor$ (the grey relational value is 0.7065 ) , 「C10Sustainable business model marks the influences of each product on natural environment $\rfloor$ ( the grey relational value is 0.7026$)$, 「C11Sustainable business model focuses on each product's ecological footprint $\rfloor$ (the grey relational value is 0.7013 )

(5) Group Five: 「C8C8sustainable business model is beyond the companies themselves.」 (the grey relational value is 0.6912 ), 「C3Sustainable business model can reduce enterprises' influences on ecological environment $\rfloor$ (the grey relational value is 0.6856 ), $\lceil$ C1Sustainable business model can reduce business partners' enterprises' influences on ecological environment $\rfloor$ (the grey relational value is 0.6847 ) , 「C6Sustainable business model strives to reduce the greenhouse gas emissions to a minimum \rfloor (the grey relational value is 0.6838 ), 「C5Sustainable business model takes the influences of global warming on the companies' businesses into consideration $\rfloor$ (the grey relational value is 0.6815 ), C4Sustainable business model takes the issue of climate change into consideration」 (the grey relational value is 0.6772 )

(6) Group Six: 「C12Sustainable business model is apparent to stakeholders (such as shareholders)」（the grey relational value is 0.6527 ) 
Appendix 10. Literature support of survey questions

The economic dimension (A)

\begin{tabular}{|c|c|}
\hline $\begin{array}{l}\text { A1 Sustainable business model is profit } \\
\text { oriented. }\end{array}$ & $\begin{array}{l}\text { (Schaltegger, Lüdeke-Freund, and Hansen 2012) } \\
\text { (Bocken et al. 2014) } \\
\text { (Jamali and Rasti-Barzoki 2018) }\end{array}$ \\
\hline $\begin{array}{l}\text { A2 Sustainable business model earns profits } \\
\text { for stakeholders. }\end{array}$ & $\begin{array}{l}\text { (Chen et al. 2005) } \\
\text { (Singh et al. 2007) } \\
\text { (Samy, Odemilin, and Bampton 2010) }\end{array}$ \\
\hline $\begin{array}{l}\text { A3 Sustainable business model is business } \\
\text { driven. (For example, it is established } \\
\text { based on corporate objectives.) }\end{array}$ & $\begin{array}{l}\text { (Schaltegger et al. 2012) } \\
\text { (Dyllick and Rost 2017) }\end{array}$ \\
\hline $\begin{array}{l}\text { A4 Sustainable business model is } \\
\text { committed to reducing costs. }\end{array}$ & $\begin{array}{l}\text { (Li et al. 2010) } \\
\text { (Bocken et al. 2014) }\end{array}$ \\
\hline $\begin{array}{l}\text { A5 Sustainable business model improves } \\
\text { cost-effectiveness }\end{array}$ & $\begin{array}{l}\text { (Singh et al. 2007) } \\
\text { (Global Reporting Initiative 2014) (Luqmani, Leach, and Jesson } \\
\text { 2017) }\end{array}$ \\
\hline $\begin{array}{l}\text { A6 Sustainable business model reduces } \\
\text { business spending. }\end{array}$ & $\begin{array}{l}\text { (Dyllick and Rost 2017) } \\
\text { (de Medeiros and Ribeiro 2017) }\end{array}$ \\
\hline $\begin{array}{l}\text { A7 Sustainable business model promotes } \\
\text { enterprises' competitive position }\end{array}$ & $\begin{array}{l}\text { (Pujari, Wright, and Peattie 2003) } \\
\text { (Saeidi et al. 2015) } \\
\text { (Jamali and Rasti-Barzoki 2018) }\end{array}$ \\
\hline $\begin{array}{l}\text { A8 Sustainable business model establishes } \\
\text { competitive advantage. }\end{array}$ & $\begin{array}{l}\text { (Bocken et al. 2014) } \\
\text { (Saeidi et al. 2015) } \\
\text { (Zhu and Sarkis 2016) }\end{array}$ \\
\hline $\begin{array}{l}\text { A9 Sustainable business model is the key } \\
\text { factor for business success }\end{array}$ & (Long, Looijen, and Blok 2018) \\
\hline
\end{tabular}




\begin{tabular}{|c|c|}
\hline & (Piscicelli, Ludden, and Cooper 2018) \\
\hline $\begin{array}{l}\text { A10 Sustainable business model promotes } \\
\text { enterprises' image in the market }\end{array}$ & $\begin{array}{l}\text { (McAdam and Leonard 2003) } \\
\text { (Dangelico and Vocalelli 2017) }\end{array}$ \\
\hline $\begin{array}{l}\text { A11 Sustainable business model improves } \\
\text { corporate reputation }\end{array}$ & $\begin{array}{l}\text { (Fombrun 2005) } \\
\text { (Sethi, Martell, and Demir 2016) }\end{array}$ \\
\hline $\begin{array}{l}\text { A12 Sustainable business model positively } \\
\text { enhances the relationship of enterprises } \\
\text { and their stakeholders }\end{array}$ & $\begin{array}{l}\text { (Steurer et al. 2005) } \\
\text { (Williams and Dair 2007) }\end{array}$ \\
\hline $\begin{array}{l}\text { A13 Sustainable business model brings the } \\
\text { unexpected opportunity for the } \\
\text { company }\end{array}$ & $\begin{array}{l}\text { (Cohen and Winn 2007) } \\
\text { (Cooperrider 2008) }\end{array}$ \\
\hline $\begin{array}{l}\text { A14 Sustainable business model brings } \\
\text { unexpected benefits for companies }\end{array}$ & $\begin{array}{l}\text { (Samy et al. 2010) } \\
\text { (Piscicelli et al. 2018) }\end{array}$ \\
\hline $\begin{array}{l}\text { A15 Sustainable business model has a } \\
\text { positive contribution to the business of } \\
\text { companies' other businesses }\end{array}$ & $\begin{array}{l}\text { (Hart and Milstein 2003) } \\
\text { (Figge and Hahn 2004) } \\
\text { (Porter and Kramer 2011) }\end{array}$ \\
\hline $\begin{array}{l}\text { A16 Sustainable business model influences } \\
\text { corporate decision-making in non- } \\
\text { economic aspect }\end{array}$ & $\begin{array}{l}\text { (Singh et al. 2007) } \\
\text { (Hallstedt 2017) }\end{array}$ \\
\hline $\begin{array}{l}\text { A17 Sustainable business model leads to } \\
\text { the reallocation of resources }\end{array}$ & $\begin{array}{l}\text { (Martínez-Ferrero and Frías-Aceituno 2015) } \\
\text { (Ortiz-de-Mandojana and Bansal 2015) }\end{array}$ \\
\hline $\begin{array}{l}\text { A18 Sustainable business model allows } \\
\text { companies to conduct economic trade- } \\
\text { off selection }\end{array}$ & $\begin{array}{l}\text { (Beckmann, Hielscher, and Pies 2014) } \\
\text { (Jamali and Rasti-Barzoki 2018) }\end{array}$ \\
\hline $\begin{array}{l}\text { A19 Sustainable business model improves } \\
\text { the use of working capital }\end{array}$ & $\begin{array}{l}\text { (van Kleef and Roome 2007) } \\
\text { (Saeidi et al. 2015) } \\
\text { (de Medeiros and Ribeiro 2017) }\end{array}$ \\
\hline
\end{tabular}




\begin{tabular}{|c|l|}
\hline $\begin{array}{c}\text { A20 Sustainable business model brings } \\
\text { financial benefits for companies }\end{array}$ & $\begin{array}{l}\text { (Martínez-Ferrero and Frías-Aceituno 2015) } \\
\text { (de Medeiros and Ribeiro 2017) }\end{array}$ \\
\hline $\begin{array}{c}\text { A21 Sustainable business model improves } \\
\text { companies' financial performance }\end{array}$ & (Ortiz-de-Mandojana and Bansal 2015) \\
& (Martínez-Ferrero and Frías-Aceituno 2015) \\
\hline
\end{tabular}

The social dimension (B)

\begin{tabular}{|c|c|}
\hline $\begin{array}{l}\text { B1 Sustainable operation model shall have } \\
\text { common ambitions with the companies' } \\
\text { business networks. }\end{array}$ & $\begin{array}{l}\text { (Hamann 2003) } \\
\text { (Luqmani et al. 2017) } \\
\text { (Dyllick and Rost 2017) }\end{array}$ \\
\hline $\begin{array}{l}\text { B2 Sustainable operation model shall have } \\
\text { common ambitions with the companies' } \\
\text { business networks. }\end{array}$ & $\begin{array}{l}\text { (Hamann 2003) } \\
\text { (Luqmani et al. 2017) } \\
\text { (Dyllick and Rost 2017) }\end{array}$ \\
\hline $\begin{array}{l}\text { B3 Sustainable operation model shall be used } \\
\text { by all business partners of the companies. }\end{array}$ & $\begin{array}{l}\text { (Hamann 2003) } \\
\text { (Clark et al. 2009) }\end{array}$ \\
\hline $\begin{array}{l}\text { B4 Sustainable operation model is meaningless } \\
\text { without the support of company employees. }\end{array}$ & $\begin{array}{l}\text { (Singh et al. 2007) } \\
\text { (Bos-Brouwers 2010) }\end{array}$ \\
\hline $\begin{array}{l}\text { B5 Sustainable operation model has no } \\
\text { influence without the support of companies' } \\
\text { leaderships. }\end{array}$ & $\begin{array}{l}\text { (van Kleef and Roome 2007) } \\
\text { (Eccles, Perkins, and Serafeim 2012) }\end{array}$ \\
\hline $\begin{array}{l}\text { B6 Sustainable operation model has no } \\
\text { influence without the support of companies' } \\
\text { leaderships. }\end{array}$ & $\begin{array}{l}\text { (van Kleef and Roome 2007) } \\
\text { (Eccles, Perkins, and Serafeim 2012) }\end{array}$ \\
\hline $\begin{array}{l}\text { B7 Sustainable operation model reflects } \\
\text { corporate norms. }\end{array}$ & $\begin{array}{l}\text { (Bansal 2002) } \\
\text { (Fombrun 2005) }\end{array}$ \\
\hline $\begin{array}{l}\text { B8 Sustainable operation model can show } \\
\text { corporate value. }\end{array}$ & $\begin{array}{l}\text { (Hart and Milstein 2003) } \\
\text { (Figge and Hahn 2004) }\end{array}$ \\
\hline
\end{tabular}




\begin{tabular}{|c|c|}
\hline $\begin{array}{l}\text { B9 Sustainable operation model is established } \\
\text { based on business principles. }\end{array}$ & $\begin{array}{l}\text { (Bansal 2002) } \\
\text { (Global Reporting Initiative 2014) } \\
\text { (Hallstedt 2017) }\end{array}$ \\
\hline $\begin{array}{l}\text { B10 The operation results of } \\
\text { sustainable operation model positively } \\
\text { enhance companies' reputation. }\end{array}$ & $\begin{array}{l}\text { (Fombrun 2005) } \\
\text { (Saeidi et al. 2015) }\end{array}$ \\
\hline $\begin{array}{l}\text { B11 The operation of sustainable } \\
\text { operation model has a positive impact on } \\
\text { companies' reputation. }\end{array}$ & $\begin{array}{l}\text { (Elkington 1994) } \\
\text { (Sethi et al. 2016) }\end{array}$ \\
\hline $\begin{array}{c}\text { B12 Sustainable operation model } \\
\text { gains good evaluation from stakeholders. }\end{array}$ & $\begin{array}{l}\text { (Steurer et al. 2005) } \\
\text { (Matos and Silvestre 2013) }\end{array}$ \\
\hline $\begin{array}{l}\text { B13 The operation of sustainable } \\
\text { operation model requires enterprises to put a } \\
\text { lot of efforts. }\end{array}$ & $\begin{array}{l}\text { (Bos-Brouwers 2010) } \\
\text { (Bocken et al. 2014) }\end{array}$ \\
\hline $\begin{array}{l}\text { B14 The operation of sustainable } \\
\text { operation model requires enterprises to } \\
\text { invest a lot. }\end{array}$ & $\begin{array}{l}\text { (Samy et al. 2010) } \\
\text { (Martínez-Ferrero and Frías-Aceituno 2015) }\end{array}$ \\
\hline $\begin{array}{l}\text { B15 The operation of sustainable } \\
\text { operation model is established based on } \\
\text { dedication. }\end{array}$ & $\begin{array}{l}\text { (Figge and Hahn 2004) } \\
\text { (Singh et al. 2007) } \\
\text { (Beckmann et al. 2014) }\end{array}$ \\
\hline $\begin{array}{l}\text { B16 Sustainable operation model is } \\
\text { established based on business continuity. }\end{array}$ & $\begin{array}{l}\text { (Young and Tilley 2006) } \\
\text { (Luqmani et al. 2017) } \\
\text { (Piscicelli et al. 2018) }\end{array}$ \\
\hline $\begin{array}{l}\text { B17 The operation of sustainable } \\
\text { operation model requires the consistency of } \\
\text { companies' decisions. }\end{array}$ & $\begin{array}{l}\text { (Hallstedt 2017) } \\
\text { (Papadas, Avlonitis, and Carrigan 2017) }\end{array}$ \\
\hline
\end{tabular}




\begin{tabular}{|c|l|}
\hline $\begin{array}{l}\text { B18 Sustainable operation model is } \\
\text { performed with the agreement of all } \\
\text { colleagues of the companies. }\end{array}$ & $\begin{array}{l}\text { (Bansal 2002) } \\
\text { (Eccles et al. 2012) }\end{array}$ \\
\hline $\begin{array}{c}\text { Sustainable operation model is } \\
\text { available to public supervision. }\end{array}$ & (Samy et al. 2010) \\
Sustainable operation model is & (Samy et al. 2010) \\
open and transparent publicly. & (Greenpeace 2017) \\
\hline Sustainable operation model & (Hart and Milstein 2003) \\
can be widely reported. & (Schneider and Meins 2012) \\
\hline
\end{tabular}

The environmental dimension (C):

\begin{tabular}{|c|c|}
\hline $\begin{array}{l}\text { C1 Sustainable operation model can reduce } \\
\text { business partners' enterprises' influences on } \\
\text { ecological environment. }\end{array}$ & $\begin{array}{l}\text { (Baumann, Boons, and Bragd 2002) } \\
\text { (Clark et al. 2009) } \\
\text { (Dangelico and Vocalelli 2017) }\end{array}$ \\
\hline $\begin{array}{l}\text { C2 Sustainable operation model takes the } \\
\text { influences of the partners' enterprises on } \\
\text { ecological environment into consideration. }\end{array}$ & $\begin{array}{l}\text { (Madani and Rasti-Barzoki 2017) } \\
\text { (Greenpeace 2017) } \\
\text { (Apple 2017) }\end{array}$ \\
\hline $\begin{array}{l}\text { C3 Sustainable operation model can reduce } \\
\text { enterprises' influences on ecological } \\
\text { environment. }\end{array}$ & $\begin{array}{l}\text { (Samy et al. 2010) } \\
\text { (Global Reporting Initiative 2014) }\end{array}$ \\
\hline $\begin{array}{l}\text { C4 Sustainable operation model takes the issue } \\
\text { of climate change into consideration. }\end{array}$ & $\begin{array}{l}\text { (Global Reporting Initiative 2014) } \\
\text { (Sethi et al. 2016) } \\
\text { (Greenpeace 2017) }\end{array}$ \\
\hline $\begin{array}{l}\text { C5 Sustainable operation model takes the } \\
\text { influences of global warming on the } \\
\text { companies' businesses into consideration. }\end{array}$ & $\begin{array}{l}\text { (Singh et al. 2007) } \\
\text { (Clark et al. 2009) } \\
\text { (Global Reporting Initiative 2014) }\end{array}$ \\
\hline
\end{tabular}




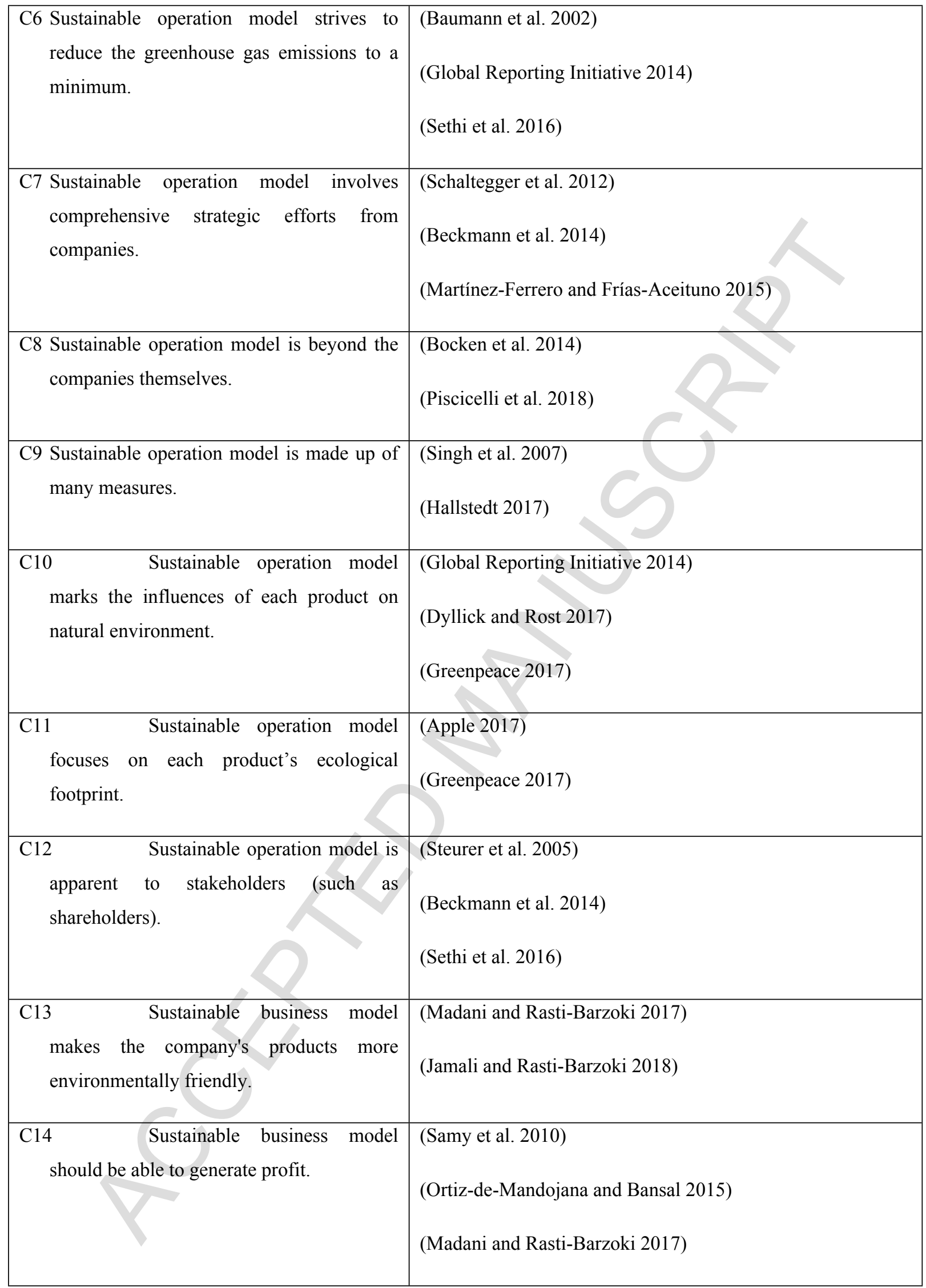




\begin{tabular}{|c|c|}
\hline $\begin{array}{l}\text { C15 Sustainable operation model } \\
\text { helps to hold activities about the influences } \\
\text { of products on ecological environment. }\end{array}$ & $\begin{array}{l}\text { (Global Reporting Initiative 2014) } \\
\text { (Greenpeace 2017) } \\
\text { (Piscicelli et al. 2018) }\end{array}$ \\
\hline $\begin{array}{l}\text { C16 Sustainable operation model is } \\
\text { considered to be suitable in natural } \\
\text { environment protection. }\end{array}$ & $\begin{array}{l}\text { (Global Reporting Initiative 2014) } \\
\text { (Greenpeace 2017) }\end{array}$ \\
\hline $\begin{array}{l}\text { C17 The quality of sustainable } \\
\text { operation model is strictly controlled } \\
\text { through continuous improvement. }\end{array}$ & $\begin{array}{l}\text { (McAdam and Leonard 2003) } \\
\text { (Clark et al. 2009) } \\
\text { (Long et al. 2018) }\end{array}$ \\
\hline $\begin{array}{l}\text { C18 Sustainable operation model is } \\
\text { a continuous process. }\end{array}$ & $\begin{array}{l}\text { (Bocken et al. 2014) } \\
\text { (Ortiz-de-Mandojana and Bansal 2015) }\end{array}$ \\
\hline
\end{tabular}

\section{Other literature references used by supporting survey questions:}

Apple. 2017. "Environmental Responsibility Report 2017.” Apple.

Bansal, Pratima. 2002. "The Corporate Challenges of Sustainable Development." Academy of Management Executive 16(2):122-31.

Baumann, H., F. Boons, and A. Bragd. 2002. "Mapping the Green Product Development Field: Engineering, Policy and Business Perspectives." Journal of Cleaner Production 10(5):409-25.

Beckmann, Markus, Stefan Hielscher, and Ingo Pies. 2014. "Commitment Strategies for Sustainability: How Business Firms Can Transform Trade-Offs Into Win-Win Outcomes." Business Strategy and the Environment 23(1):18-37.

Bocken, N. M. P., S. W. Short, P. Rana, and S. Evans. 2014. “A Literature and Practice Review to Develop Sustainable Business Model Archetypes.”Journal of Cleaner Production 65:42-56.

Bos-Brouwers, Hilke Elke Jacke. 2010. “Corporate Sustainability and Innovation in SMEs: Evidence of Themes and Activities in Practice." Business Strategy and the Environment 19(7):417-35.

Chen, Zhilan, Yan-Leung Cheung, Aris Stouraitis, and Anita W. S. Wong. 2005. “Ownership Concentration, Firm Performance, and Dividend Policy in Hong Kong.” Pacific-Basin Finance Journal 13:431-49.

Clark, Garrette, Justin Kosoris, Long Nguyen Hong, and Marcel Crul. 2009. "Design for Sustainability: Current Trends in Sustainable Product Design and Development." Sustainability. 
Cohen, Boyd and Monika I. Winn. 2007. "Market Imperfections, Opportunity and Sustainable Entrepreneurship.” Journal of Business Venturing 22(1):29-49.

Cooperrider, David. 2008. “Sustainable Innovation.” BizEd 7(4):32-38.

Dangelico, Rosa Maria and Daniele Vocalelli. 2017. “'Green Marketing': An Analysis of Definitions, Strategy Steps, and Tools through a Systematic Review of the Literature.” Journal of Cleaner Production.

Dyllick, Thomas and Zoe Rost. 2017. "Towards True Product Sustainability.” Journal of Cleaner Production $162: 346-60$.

Eccles, R. G., Km Perkins, and George Serafeim. 2012. "How to Become a Sustainable Company.” MIT Sloan Management Review 53(4):43-50.

Elkington, John. 1994. "Towards the Sustainable Corporation: Win-Win-Win Business Strategies for Sustainable Development." California Management Review 36(2):90-100.

Figge, Frank and Tobias Hahn. 2004. "Sustainable Value Added - Measuring Corporate Contributions to Sustainability beyond Eco-Efficiency.” Ecological Economics 48(2):173-87.

Fombrun, Charles J. 2005. “A World of Reputation Research, Analysis and Thinking — Building Corporate Reputation Through CSR Initiatives: Evolving Standards.” Corporate Reputation Review 8(1):7-12.

Global Reporting Initiative. 2014. “G4 Sustainability Reporting Guidelines.” Global Reporting Initiative 1-97.

Greenpeace. 2017. “Guide to Greener Electronics 2017.” October.

Hallstedt, Sophie I. 2017. "Sustainability Criteria and Sustainability Compliance Index for Decision Support in Product Development." Journal of Cleaner Production 140:251-66.

Hamann, Ralph. 2003. "Mining Companies' Role in Sustainable Development." The Why and How of Corporate Social Responsibility from a Business Perspective 20(2):237-54.

Hart, Stuart L. and Mark B. Milstein. 2003. "Creating Sustainable Value.” Academy of Management Executive 17(2):56-67.

Jamali, Mohammad Bagher and Morteza Rasti-Barzoki. 2018. "A Game Theoretic Approach for Green and NonGreen Product Pricing in Chain-to-Chain Competitive Sustainable and Regular Dual-Channel Supply Chains." Journal of Cleaner Production.

Van Kleef, J. A. G. and N. J. Roome. 2007. "Developing Capabilities and Competence for Sustainable Business Management as Innovation: A Research Agenda.” Journal of Cleaner Production 15(1):38-51.

Li, Xun et al. 2010. "Smartphone Evolution and Reuse: Establishing a More Sustainable Model.” in Proceedings of the International Conference on Parallel Processing Workshops. 
Long, Thomas B., Arnold Looijen, and Vincent Blok. 2018. "Critical Success Factors for the Transition to Business Models for Sustainability in the Food and Beverage Industry in the Netherlands." Journal of Cleaner Production 175:82-95.

Luqmani, Adam, Matthew Leach, and David Jesson. 2017. "Factors behind Sustainable Business Innovation: The Case of a Global Carpet Manufacturing Company.” Environmental Innovation and Societal Transitions 24:94-105.

Madani, Seyed Reza and Morteza Rasti-Barzoki. 2017. "Sustainable Supply Chain Management with Pricing, Greening and Governmental Tariffs Determining Strategies: A Game-Theoretic Approach.” Computers and Industrial Engineering.

Martínez-Ferrero, Jennifer and José Valeriano Frías-Aceituno. 2015. "Relationship between Sustainable Development and Financial Performance: International Empirical Research.” Business Strategy and the Environment 24(1):20-39.

Matos, Stelvia and Bruno S. Silvestre. 2013. "Managing Stakeholder Relations When Developing Sustainable Business Models: The Case of the Brazilian Energy Sector.” Journal of Cleaner Production 45:61-73.

McAdam, Rodney and Denis Leonard. 2003. "Corporate Social Responsibility in a Total Quality Management Context: Opportunities for Sustainable Growth.” Corporate Governance 3(4):36-45.

De Medeiros, Janine Fleith and José Luis Duarte Ribeiro. 2017. "Environmentally Sustainable Innovation: Expected Attributes in the Purchase of Green Products." Journal of Cleaner Production.

Ortiz-de-Mandojana, N. and P. Bansal. 2015. "The Long-Term Benefits of Organizational Resilience through Sustainable Business Practices.” Strategic Management Journal.

Papadas, Karolos Konstantinos, George J. Avlonitis, and Marylyn Carrigan. 2017. "Green Marketing Orientation: Conceptualization, Scale Development and Validation.” Journal of Business Research.

Piscicelli, Laura, Geke D. S. Ludden, and Tim Cooper. 2018. "What Makes a Sustainable Business Model Successful? An Empirical Comparison of Two Peer-to-Peer Goods-Sharing Platforms.” Journal of Cleaner Production 172:4580-91.

Porter and Kramer. 2011. "Harvard Business Review.” Creating Shared Value 17.

Pujari, Devashish, Gillian Wright, and Ken Peattie. 2003. “Green and Competitive Influences on Environmental New Product Development Performance.” Journal of Business Research 56(8):657-71.

Saeidi, Sayyedeh Parisa Sayedeh Parastoo et al. 2015. "How Does Corporate Social Responsibility Contribute to Firm Financial Performance? The Mediating Role of Competitive Advantage, Reputation, and Customer Satisfaction." Journal of Business Research 68(2):341-50. 
Samy, Martin, Godwin Odemilin, and Roberta Bampton. 2010. "Corporate Social Responsibility: A Strategy for Sustainable Business Success. An Analysis of 20 Selected British Companies." Corporate Governance 10(2):203-17.

Schaltegger, S., Florian Lüdeke-Freund, and E. G. Hansen. 2012. "Business Cases for Sustainability: The Role of Business Model Innovation for Corporate Sustainability." International Journal of Innovation and Sustainable Development 6(2):95-119.

Schneider, Anselm and Erika Meins. 2012. "Two Dimensions of Corporate Sustainability Assessment: Towards a Comprehensive Framework.” Business Strategy and the Environment 21(4):211-22.

Sethi, S. Prakash, Terrence F. Martell, and Mert Demir. 2016. "Building Corporate Reputation through Corporate Social Responsibility (CSR) Reports: The Case of Extractive Industries." Corporate Reputation Review 19(3):219-43.

Singh, Rajesh Kumar, H. R. Murty, S. K. Gupta, and A. K. Dikshit. 2007. "Development of Composite Sustainability Performance Index for Steel Industry.” Ecological Indicators 7(3):565-88.

Steurer, Reinhard, Markus E. Langer, Astrid Konrad, and André Martinuzzi. 2005. "Corporations, Stakeholders and Sustainable Development I: A Theoretical Exploration of Business-Society Relations." Journal of Business Ethics 61(3):263-81.

Williams, Katie and Carol Dair. 2007. "What Is Stopping Sustainable Building in England? Barriers Experienced by Stakeholders in Delivering Sustainable Developments." Sustainable Development 15(3):135-47.

Young, William and Fiona Tilley. 2006. "Can Businesses Move beyond Efficiency? The Shift toward Effectiveness and Equity in the Corporate Sustainability Debate." Business Strategy and the Environment 15(6):402-15.

Zhu, Qingyun and Joseph Sarkis. 2016. "Green Marketing and Consumerism as Social Change in China: Analyzing the Literature." International Journal of Production Economics. 